\title{
Da Corte às Províncias: O desenvolvimento das Caixas Econômicas Provinciais no Império do Brasil (1874-1889)
}

\author{
Thiago Alvarenga de Oliveira \\ Universidade Federal Fluminense
}

\section{Resumen}

As caixas econômicas no Brasil datam do começo da década de 1830 . No entanto, o governo brasileiro cria sua primeira caixa econômica em 1861 na cidade do Rio de Janeiro. Devido ao desenvolvimento dessa caixa, o governo imperial resolveu expandir esse modelo para cada capital de província brasileira a partir de 1874. A proposta desse artigo é apresentar uma análise do desenvolvimento da poupança brasileira por meio das caixas econômicas provinciais administradas pelo governo imperial brasileiro e fazer uma comparação com os índices de crescimento com a principal caixa econômica do país, a Caixa Econômica da Corte entre 1874-1889. No limite do texto, traremos ponderações acerca do desenvolvimento dessas instituições em relação à conjuntura político-econômica específica de cada capital provincial. O texto está dividindo em quatro partes. A primeira retrocede o recorte cronológico da proposta para fazer uma breve história da poupança e das principais caixas econômicas do Brasil anteriores a criação da Caixa Econômica da Corte em 1861. A segunda discorre brevemente sobre a reforma estatutária das caixas econômicas em 1874 e a forma administrativa adotada para todas as caixas econômicas provinciais do Império do Brasil. A terceira, núcleo central do artigo, analisa o desenvolvimento dos depósitos das caixas econômicas provinciais nas duas décadas do Império do Brasil, bem como relaciona ao crescimento demográfico das províncias entre os recenseamentos de 1872 e 1890. A quarta, e última parte, trata das conclusões obtidas nas análises geral das caixas econômicas provinciais..

\section{Palabras clave}

Caixas Econômicas; Brasil; Século XIX; Depósitos; Rio de Janeiro

Códigos JEL: N26, N36, N96, G21
FROM THE COURT TO THE PROVINCES: THE DEVELOPMENT OF THE PROVINCIAL SAVINGS BANKS OF THE BRAZIL EMPIRE (18741889)

\section{Abstract}

Savings banks in Brazil date from the early 1830s. However, the Brazilian government created its first savings bank in 1861 in the city of Rio de Janeiro. Due to the development of this savings bank, the imperial government decided to expand this model to each Brazilian provincial capital from 1874. The purpose of this article is to present an analysis of the development of Brazilian savings through the provincial savings banks administered by the Brazilian imperial government and to make a comparison with the growth rates of the country's main savings bank - Caixa Econômica da Corte - between 1874-1889. At the limit of the text, we will consider the development of these institutions in relation to the specific political and economic situation of each provincial capital. The text is dividing into four parts. The first goes back to the chronological outline of the proposal to make a brief history of savings and the savings banks in Brazil prior to the creation of Caixa Econômica da Corte in 1861. The second briefly discusses the statutory reform of savings banks in 1874 and the administrative form adopted for all provincial savings banks in the Empire of Brazil. The third, central core of the article, analyzes the development of deposits from provincial savings banks in the two decades of the Empire of Brazil, as well as related to the demographic growth of the provinces between the 1872 and 1890 censuses. The fourth, and last part, deals with conclusions obtained in the general analysis of the provincial savings banks.

Keywords

Savings banks; Brazil; 19th century; Deposits; Rio de Janeiro

JEL codes: N26, N36, N96, G21

Fecha de recepción del original: 3 de marzo de 2021; versión definitiva: 2 de mayo de 2021.

Thiago Alvarenga de Oliveira, Universidade Federal Fluminense

E-mail: thiagomagella@gmail.com.ORCID ID: https://orcid.org/0000-0003-3708-7456 


\section{Da Corte às Províncias: $O$ desenvolvimento das Caixas Econômicas Provinciais no Império do Brasil (1874-1889)}

Thiago Alvarenga de Oliveira

Universidade Federal Fluminense

1. Introdução

O conceito de caixa econômica foi uma ideia iluminista e utilitarista baseada no princípio da autoajuda e teve seu início no final do século XVIII em Hamburgo e Tottenham, mas rapidamente se expandiu por toda a Europa. Os agentes pioneiros compartilhavam a ideia do indivíduo ser responsável pela organização e previdência de sua vida, ao mesmo tempo, que, por serem majoritariamente membros da elite política e/ou econômica de seus países, julgavam-se obrigados a educar a virtude econômica às classes mais baixas.

No início do século XIX, com avanço da Revolução Industrial e, por consequência, a conscientização dos problemas sociais resultantes do processo de proletarização, a elite política e econômica dos países recém-industrializados incentivou o desenvolvimento das caixas econômicas no intuito de cultivar uma "moralização" do proletariado, a qual contribuiria por estabilizar a ordem social. Isso significava uma superação do "espírito da caridade" por um "espírito da previdência". Era a ideia do trabalhador se preocupar com seu próprio futuro e antecipar suas mazelas. (Horne, 1947: 90)

Ainda no começo do século XIX, os governos perceberam a capacidade econômica e social desse modelo de instituição financeira e rapidamente formaram suas próprias. Financeiramente as caixas econômicas eram capazes de atrair pequenos capitais em grandes quantidades, outrora sem a oportunidade de inserção em instituições financeiras, ou seja, as caixas econômicas eram responsáveis por concentrar os capitais dispersos das classes mais marginalizadas. Ao mesmo tempo, ao cumprir tal propósito econômico, tinha um caráter social antirrevolucionário para os governos, uma vez que direcionava os trabalhadores a inverterem suas economias e se precaverem. Portanto, isso diminuria o risco da vadiagem, de sindicalização ou revoltas.
As caixas econômicas atravessaram o oceano atlântico após a Independência dos Estados Unidos da América em 1776. A ideia, já disseminada pela Europa e, em especial, na Grã-Bretanha, foi aplicada em Boston no ano de 1816 criando dois bancos mutuais com previdência aos moldes dos "savings banks" ingleses - a Provident Institution for Savings e a Philadelphia Saving Fund Society (Sherman, 1934: 30).

Alguns anos mais tarde, em 1831, a Caixa Econômica do Rio de Janeiro foi a primeira fundada na América Latina. Essa caixa econômica instituiu o hábito da poupança em parte dos cidadãos brasileiros e teve uma longeva vida até 1859, enfrentando oposição política, depreciações dos seus ativos (todos os capitais eram invertidos em Títulos de Dívida Pública) e concorrência de outras instituições de depósitos, principalmente na década de 1850 (Alvarenga e Saraiva, 2017: 457).

Fundamentado nas experiências brasileiras desse modelo de instituição da primeira metade do século XIX, em especial da Caixa Econômica do Rio de Janeiro 1831-1859), o governo lança as bases da criação da sua própria caixa econômica em 1860 por meio da Lei no 1.083 de 22 de agosto de 1860 (Lei dos Entraves). Alguns meses mais tarde, a Caixa Econômica da Corte é inaugurada e, após mais de uma década de existência, com rápido desenvolvimento no número de depósitos e valores depositados, o governo decide expandi-la para todas as capitais de província em 1874.

A proposta desse texto é apresentar uma análise da poupança coligida em cada caixa econômica provincial administrava pelo governo imperial e a comparação do desenvolvimento entre a principal caixa econômica do país, isto é, a Caixa Econômica da Corte com as demais caixas provinciais. No limite do texto, traremos ponderações acerca do desenvolvimento dessas instituições em relação à conjuntura políticoeconômica específica de cada capital provincial.

O texto está dividindo em quatro partes além dessa introdução. A primeira retrocede o recorte cronológico da proposta para fazer uma breve história da poupança e das principais instituições de poupança do Brasil anteriores a criação da Caixa 
Econômica da Corte em 1861. A segunda discorre brevemente sobre a reforma estatutária das caixas econômicas em 1874 e a forma administrativa adotada para todas as caixas econômicas provinciais do Império do Brasil. A terceira, núcleo central do artigo, analisa o desenvolvimento dos depósitos das caixas econômicas provinciais nas duas décadas do Império do Brasil, bem como relaciona ao crescimento demográfico das províncias entre os recenseamentos de 1872 e 1890. A quarta, e última parte, trata das conclusões obtidas nas análises geral das caixas econômicas provinciais.

\section{A breve história da poupança brasileira nos oitocentos}

Até que se prove o contrário, a Caixa Econômica do Rio de Janeiro foi a primeira experiência de caixa econômica aos moldes europeus no Brasil. A instituição foi fundada na capital do império em 1831 por comerciantes, jornalistas, profissionais liberais, funcionários públicos, fazendeiros e políticos alinhados ao campo liberal e que estavam ligados ao processo que levou à abdicação de D. Pedro I em 1831 (Alvarenga e Saraiva, 2017: 430).

Os estatutos da Caixa Econômica do Rio de Janeiro foram extraídos diretamente da Caisse D'Épargne de Paris, fundada em 1818. Esse modelo de instituição se caracterizava pelo paternalismo, pela disciplina e moralização econômica e investimentos em ativos públicos (Christen-Lecuyer, 2005). O paternalismo estava explícito na exigência que as mulheres, menores e escravos fossem autorizados pelos seus respectivos maridos, pais ou tutores e senhores. Além disso, a questão de uma instituição de origem europeia, criada pelos bons homens da sociedade carioca, tinha uma obrigação fundacional de moralizar os brasileiros nos termos da economia e previdência. Essa moralização se dava por meio de notas nos periódicos exaltando os benefícios de se poupar pequenas quantias ao longo dos tempos, bem como por meio da tradução de uma novela/conto francês, no qual o protagonista se salva de situações perniciosas por ser um poupador da caixa econômica (Alvarenga e Saraiva, 2017: 434).

Por fim, o investimento em ativos públicos estava relacionado à necessidade de construir um Estado no contexto da Regência Brasileira (1831-1840). A Caixa Econômica do Rio de Janeiro, ainda que privada, assegurava todo o capital acumulado de seus poupadores na compra de Títulos de Dívida Pública. Essa forma de investimento foi extremamente rentável para Caixa em um momento de conturbação político-econômica brasileira, fazendo-a assumir o papel de maior possuidor desses títulos do governo, acumulando um total de aproximadamente 3.500 contos de réis em Títulos de Dívida Pública no ano de 1838. Na década seguinte, o governo brasileiro interrompe o resgate desses títulos, fazendo-o seu preço de mercado cair. Dessa forma, o principal investimento da Caixa
Econômica do Rio de Janeiro se desvalorizava, tendo seus valores de face reduzidos de $85 \%$ para $70 \%$ ainda no ano de 1838 (Alvarenga e Saraiva, 2017: 440).

A instituição sobreviveu ao final da década de 1840 e ganhou uma sobrevida no início da década seguinte, porém a situação ficaria crítica no ano de 1857 em função da crise mundial. Os efeitos da crise ainda são discutidos na historiografia econômica brasileira, mas parece claro que os ingleses - principais credores da praça comercial do Rio de Janeiro - começaram a aceitar pagamentos apenas em espécie, o que acarretou numa evasão de divisas sem precedentes, ao mesmo tempo que diminuíra a quantidade de moeda em circulação no Rio de Janeiro. Esses efeitos diminuíram a média da taxa de juros de $11 \%$ para $8 \%$ e, por consequência, os valores dos Títulos de Dívida Pública caíram ainda mais (Guimarães, 2013).

O conselho da Caixa Econômica do Rio de Janeiro ainda tentou solucionar os problemas ao enviar para o governo as mudanças nos estatutos, alterando principalmente a questão da centralização dos investimentos nos Títulos de Dívida Pública e se transformando em uma sociedade anônima capaz de emprestar e descontar letras. O pedido de mudança de estatuto foi negado duas vezes pelo governo, o qual não permitia que caixas econômicas se transformassem em instituição de especulação mercantil. Os pareceres da reprovação desse novo estatuto foram assinados por importantes nomes do Partido Conservador já à frente do governo imperial e compondo o que é chamado na historiografia como Direção Saquarema (Mattos, 2004).

A situação se tornou insustentável. Criticado constantemente nos períodos por seus poupadores, propostas de mudanças recusadas pelo governo e ampla concorrência das casas bancárias na praça comercial do Rio de Janeiro. Em outubro de 1859, a Caixa Econômica do Rio de Janeiro fecha suas portas em decisão de seus principais poupadores.

No momento de sua liquidação, a Caixa Econômica do Rio de Janeiro já convivia com a forte concorrência das casas bancárias cariocas, as quais acumulavam significativas somas de capitais de pequenos e grandes poupadores. Essas casas bancárias não eram bancos, não eram instituições beneficentes e não estavam registradas como Sociedades Anônimas. De fato, as casas bancárias eram registradas como firmas na Junta Comercial e atuavam intermediando os grandes negociantes e bancos no Rio de Janeiro. As casas bancárias se tornaram instituições de grande valor principalmente após a Lei dos Entraves de 1860, a qual restringia a capacidade dos bancos de emitir moeda (Alvarenga e Mantuano, 2020: 7).

Para atender a demanda de crédito e, ao mesmo tempo, constituir capital para isso, as casas bancárias trabalhavam captando economias nas duas pontas da sociedade carioca: de um lado, os bancos, principais interessados em driblar a restrição monetária da lei de 1860, se constituíam como os principais credores das casas bancárias; do outro, as casas bancárias se constituíram como caixas depositárias, com características de caixas econômicas, uma vez que acumulavam larga soma de economias de inúmeros clientes, sendo a maior parte considerados pequenos credores, compondo a camada mais popular da sociedade carioca, inclusive escravos (Alvarenga, 2018). 
As casas bancárias se desenvolveram rapidamente na década de 1850 e início do decênio seguinte. No entanto, não conseguiram manter a reprodução do sistema nas duas pontas (crédito e depósito), principalmente em decorrência do aumento dos juros praticados na praça comercial do Rio de Janeiro. Dessa forma, recorriam a empréstimos periódicos ao Banco do Brasil para cobrir seus déficits. Em setembro de 1864, tendo o empréstimo negado pelo Banco do Brasil, a maior e mais prestigiada casa bancária na Corte - A. J. Alves Souto \& $\mathrm{Cia}$ - fecha suas portas, causando um verdadeiro pânico e, consequentemente, corrida para saques em várias casas bancárias da cidade do Rio de Janeiro (Alvarenga e Mantuano, 2020: 15).

A consequência imediata foi a declaração de liquidação por quatro casas bancárias, nas quais coligiam aproximadamente 68.467 contos de réis em depósitos. Devido ao inquérito instaurado para lidar com a crise de 1864 (conhecida como Crise do Souto), listas nominativas dos clientes das casas bancárias foram publicadas nos periódicos da cidade. Excetuando as contas não-identificadas, havia um total de 62 escravos, 11 forros, 18 menores, 18770 livres, 568 pessoas jurídicas (Alvarenga, 2018: 265).

O governo já administrava sua própria caixa econômica no momento da crise, no entanto, o desenvolvimento dela era lento e irrisório se comparado com as casas bancárias. Dessa maneira, a crise de 1864 foi o momento ideal para o governo capitalizar as economias na Corte. Por meio da propaganda incessante nos periódicos, a administração da Caixa Econômica da Corte apostou na "garantia do Governo Imperial" para concentrar os capitais em sua instituição (Alvarenga, 2020: 117).

Importante ressaltar que a Caixa Econômica da Corte era administrada em conjunto com o Monte de Soccorro da Corte. As duas instituições foram criadas pelo decreto de $n^{\circ} 2.723$, de 12 de janeiro de 1861 e funcionam numa espécie de binômio Monte de Soccorro / Caixa Econômica, no qual os lucros advindos do crédito por penhores eram responsáveis pela manutenção dos funcionários que trabalhavam nessas duas instituições sob o mesmo teto. Ao entrar na disputa por captação de poupança e fornecimento do pequeno crédito por meio do penhor, o governo buscava centralizar as pequenas economias urbanas.

O desenvolvimento da Caixa Econômica da Corte, administrada por conselheiros indicados pelo Ministro da Fazenda, acontece ao longo da Guerra do Paraguai. Momento conturbado da história brasileira, no entanto, com uma significativa emissão de papel-moeda para cobrir os gastos da guerra. Entremeio a isso, o governo teve seu laboratório com a Caixa Econômica da Corte passando por pequenas reformas em seus estatutos e expandindo o quadro de funcionários devido a demanda. No intuito de expandir mais um instrumento para sanar as contas públicas, em 1874, o Visconde do Rio Branco, enquanto chefe de gabinete, determinou o momento para a criação das caixas econômicas províncias em cada capital de província do Império aos moldes da Caixa Econômica da Corte (Alvarenga, 2020: 207).

O hábito de poupança, difundido inicialmente pela Caixa Econômica do Rio de Janeiro (1831-1859), já estava consolidado nos principais centros urbanos. No momento de expansão das caixas econômicas províncias do governo imperial já existia caixas econômicas particulares em algumas capitais e poucos municípios do império brasileiro. Discutiremos a respeito do desenvolvimento das caixas econômicas provinciais, bem como a concorrência encontrada em algumas capitais no restante do artigo.

\section{A Expansão das Caixas Econômicas Provinciais}

Nosso objetivo, nesse texto, é tratar da expansão das caixas econômicas provinciais em comparação com o desenvolvimento da Caixa Econômica da Corte. Pelo limite de nosso objetivo, não pretendemos avançar nos motivos econômicos que dificultaram ou propiciaram o desenvolvimento das caixas econômicas em cada província, mas sim compreender os ritmos de desenvolvimento de cada uma.

O regulamento promulgado por meio do Decreto n. 5594 de 18 de abril de 1874 reproduzia o estatuto da Caixa Econômica e Monte de Soccorro da Corte à nível nacional com alguns novos dispositivos, como: a incorporação da obrigatoriedade de permissão do Juízo de Orphãos e Ausentes no caso de saque de contas de escravos; a exclusão do condicionamento de seus maridos para operações das contas de clientes mulheres; bem como a reformulação do modelo de escrituração e administração das contas (cadernetas ou penhores) e a constituição de um novo quadro técnico com a figura de um gerente para prestar contas ao Conselho Inspector e Fiscal da Caixa Econômica e Montes de Soccorro, o qual por sua vez presta contas ao Ministério da Fazenda anualmente.

Além de decretar a criação de Caixas Econômicas e Montes de Soccorro em cada capital de província do império brasileiro, esse decreto determinou a criação de agências da Caixa Econômica nos principais municípios da província do Rio de Janeiro. A província fluminense, tal como fora a Corte, se tornava um laboratório para a instituição de depósitos do governo.

As caixas econômicas provinciais já eram requisitadas pelas capitais das províncias imperiais. Era possível verificar a demanda ao reparar o desenvolvimento de caixas econômicas particulares em algumas das principais cidades do império, como por exemplo: a Caixa Econômica de Ouro Preto, a Caixa de Economias de Salvador, a outra de Salvador, a Caixa Econômica de São Paulo, a Caixa Econômica de Campos, entre outras.

Por mais que algumas dessas instituições investissem em compras de ativos públicos, a centralização dos depósitos exercida pelo governo imperial na Corte com a criação da Caixa Econômica da Corte demostrava um desenvolvimento significativo, portanto, a expansão se tornava interessante para, principalmente, remediar as contas públicas ao centrar grande parte dos mil-réis não inseridos no sistema financeiro ao Thesouro Nacional.

Para instaurar as caixas econômicas e os montes de soccorro nas capitais de cada província, o governo imperial determi- 
nou o requisito de capital de 25 contos iniciais. Esse valor seria coletado por meio de $1 \%$ dos capitais advindos das loterias e dos primeiros depositantes das caixas econômicas provinciais, as quais poderiam receber imediatamente. Ademais, o Barão do Rio Grande, presidente do conselho da caixa econômica e monte de soccorro da Corte, demandava aos presidentes de cada conselho provincial que não medissem esforços e, até mesmo, fizessem empréstimos, como algumas províncias fizeram, para iniciar as atividades dessas duas instituições:

Sendo necessária a quantia de 25:000\$000 para os Montes de Soccorro começarem suas operações, na Província do Espírito Santo o Presidente obteve essa somma, por empréstimo, do cidadão Francisco Pinto de Oliveira; na de Minas Geraes a Assembléa Provincial autorizou o respectivo Presidente a emprestal-a; na de Mato Grosso, cujo Conselho Fiscal reuniu-se pela primeira vez em 28 de Março último, o mesmo Conselho resolveu adiantal-a; e é de esperar que tão louvável exemplo seja imitado nas outras províncias (Brasil, 1874).

Mesmo com as súplicas do presidente da Caixa Econômica e Monte de Soccorro, algumas caixas econômicas e montes de soccorro provinciais tiveram dificuldade para iniciar suas atividades e postergaram suas inaugurações. Muitas dessas caixas econômicas provinciais foram fundadas com ajuda de empréstimos realizados por membros do Conselho Inspector e Fiscal Fundacional locais. As datas de início das atividades das instituições de depósito do governo podem ser vistas na Tabela 1.

Todas as caixas econômicas provinciais tiveram dificuldades para se desenvolverem inicialmente. A administração na forma de binômio Monte de Soccorro / Caixa Econômica determinava que os juros obtidos pelos empréstimos sob penhores fossem responsáveis pela manutenção dos funcionários de ambas as instituições. Essa forma administrativa atravancou o início do desenvolvimento de tais instituições, as quais recorriam frequentemente ao governo imperial para auxílios. O governo interveio sempre que julgou necessário, acatando pedidos de alteração dos juros sob as poupanças, bem como auxiliando por meio de concessões de $1 \%$ dos valores das loterias do governo.

O Mapa 1 revela a dimensão da diferença dos volumes de capitais entre as caixas econômicas provinciais para a Caixa Econômica da Corte no último ano sob administração do governo imperial. De um lado as Caixas Econômicas de todas as províncias, com exceção da Corte, acumularam o volume de depósitos no valor aproximado de 13.214 contos réis. É importante ressaltar que a província do Rio de Janeiro é levada em consideração nesse total, embora, na prática, o Conselho Inspector e Fiscal da Caixa Econômica da Corte fosse responsável pelas agências fluminenses. Do outro lado, somente a Caixa Econômica da Corte acumulou cerca de 11.085 contos de réis.

As seis caixas econômicas provinciais que acumularam mais capitais oriundos dos depósitos foram, em ordem decrescente, nas seguintes cidades: Salvador (3.108 contos de réis), Minas Gerais ( 1.463 contos de réis), Porto Alegre (1.184 contos de réis), São Paulo (854 contos de réis), São Luís do Maranhão (844 contos de réis) e Fortaleza (843 contos de réis). A sétima caixa econômica provincial, que demonstrou maior capacidade, foi a de Cuiabá com aproximadamente 686 contos de réis e a com o menor volume acumulado foi a de Teresina com apenas 42 contos de réis. Por fim, a província do Rio de Janeiro, excetuando, é claro, a Corte, acumulou aproximadamente 998 contos de réis por meio das suas 23 agências das caixas econômicas municipais.

Tabela 1. Início das atividades de cada Caixa Econômica e Monte de Soccorro provinciais no Brasil

\begin{tabular}{|l|l|}
\hline \multicolumn{1}{|c|}{ Capital das Províncias } & Início das Atividades \\
\hline Município Neutro (Corte) & Novembro de 1871 \\
\hline Porto Alegre (Rio Grande do Sul) & Maio de 1875 \\
\hline São Paulo (São Paulo) & Setembro de 1875 \\
\hline Ouro Preto (Minas Gerais) & Outubro de 1875 \\
\hline Cuiabá (Mato Grosso) & Outubro de 1875 \\
\hline Vitória (Espírito Santo) & Dezembro de 1875 \\
\hline Teresina (Piauí) & 1875 \\
\hline Goiânia (Goiás) & Julho de 1876 \\
\hline São Luís (Maranhão) & Julho de 1876 \\
\hline Belém (Pará) & Julho de 1876 \\
\hline Curitiba (Paraná) & Julho de 1876 \\
\hline N. S. do Desterro (Santa Catarina) & Janeiro de 1876 \\
\hline Manaus (Amazonas) & Maio de 1877 \\
\hline Recife (Pernambuco) & Junho de 1877 \\
\hline Salvador (Bahia) & Fevereiro de 1878 \\
\hline Maceió (Alagoas) & Julho de 1878 \\
\hline Fortaleza (Ceará) & Fevereiro de 1879 \\
\hline Aracajú (Sergipe) & 1885 \\
\hline Natal (Rio Grande do Norte) & 1885 \\
\hline Cidade da Paraíba (Paraíba) & 1886 \\
\hline
\end{tabular}

Fonte: Brasil, 1875-1889. Cidade da Paraíba, Natal e Teresina somente apresentaram o ano de início nos relatórios do Ministério da Fazenda. As datas referem ao início da atividade do binômio Monte de Soccorro / Caixa Econômica provinciais. As caixas econômicas provinciais começaram a captar depósitos antes dos Montes de Soccorro com a permissão do Ministério da Fazenda.

Essa desproporção fica ainda mais evidente a partir da visualização do Gráfico 1. O período exposto no gráfico compreende os anos de 1878 até 1889 , pois o ano de 1878 foi o primeiro que ano que 16 do total de 21 províncias apresentaram dados concretos de depositantes e valores depositados nas caixas econômicas. Dessa forma, podemos verificar no Gráfico 1, o desenvolvimento das caixas econômicas provinciais em relação à Caixa Econômica da Corte ao longo dos anos. O ano de 1887 para 1888 representa a superação das caixas econômicas provinciais sob a Caixa Econômica da Corte. Isso está ligado principalmente à reforma dos estatutos das caixas 
Mapa 1. Volume dos depósitos por Caixa Econômica Provincial, 1889 (réis)

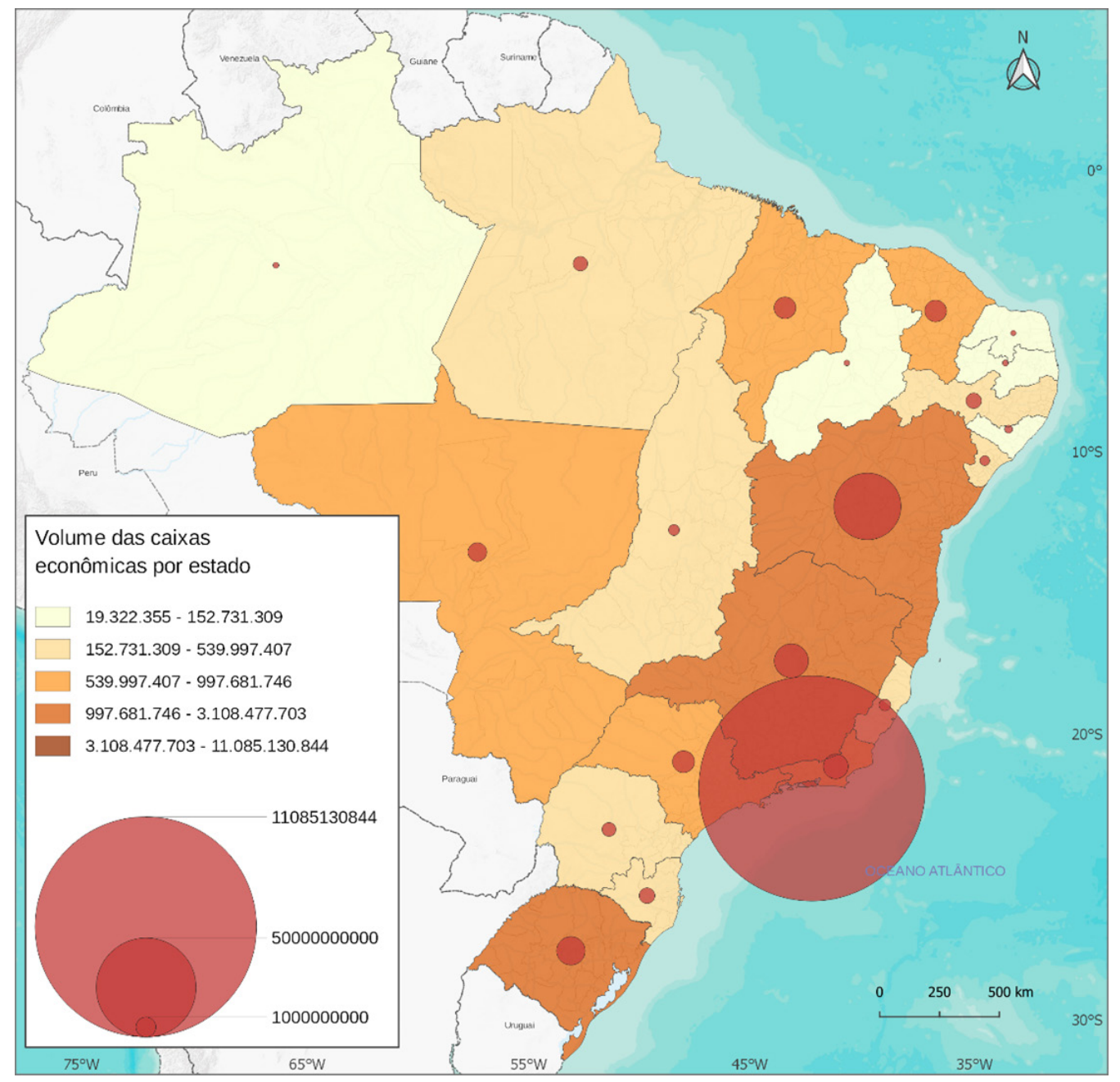

Fonte: Alvarenga, 2021.

econômicas brasileira em 1887, que determinou, dentre outras disposições, o fim do binômio Monte de Soccorro / Caixa Econômica e o do limite dos valores de depósitos semanais (Alvarenga, 2020).

Dessa forma, no começo da década de 1880, os depósitos das caixas econômicas provinciais detinham o volume de capitais depositado de aproximadamente 4.940 contos de réis. No final da década, esse volume representava 12.216 contos de réis, ou seja, um crescimento de aproximadamente $247 \%$. As caixas econômicas provinciais, criadas com mais de 10 anos de atraso em comparação à Caixa Econômica da Corte, começavam a ganhar cada vez mais importância nas contas públicas.

O desenvolvimento das caixas econômicas provinciais tardou. O objetivo da criação das caixas econômicas provinciais em 1872 foi explicitamente reduzir o número de papelmoeda em circulação. O governo imperial emitiu moeda até onde pode para arcar com os custos da Guerra do Paraguai e, por conta disso, no começo da década de 1870, estabeleceu uma política monetária de contenção. As caixas econômicas tinham, além do papel social de "disciplinar a população aos hábitos da economia e previdência", esse objetivo de enxugar a grande quantidade de papel-moeda em circulação.

O Gráfico 2 demonstra a proporção dos depósitos das caixas econômicas brasileiras em relação a quantidade de papel-moeda em circulação. Antes da Guerra do Paraguai, havia cerca de 29.094 contos de réis em circulação. Esse número é aumentado para aproximadamente 151 mil contos de réis ao final da guerra. A Caixa Econômica da Corte, até o final da Guerra do Paraguai, foi responsável por retirar de circulação o total aproximado de 4.636 contos de réis ou 3,07\% como é demonstrado no Gráfico 3.

Após o fim do conflito bélico, o governo imperial conteve a emissão de mais papel-moeda por oito anos. Ao mesmo tempo que a política monetária segurou novas emissões, a poupança brasileira foi expandida por meio da criação das caixas econômicas nas capitais do império brasileiro. Dessa forma, 
Gráfico 1. Proporção dos depósitos da Caixa Econômica da Corte e suas agências com a soma das Caixas Econômicas Provinciais

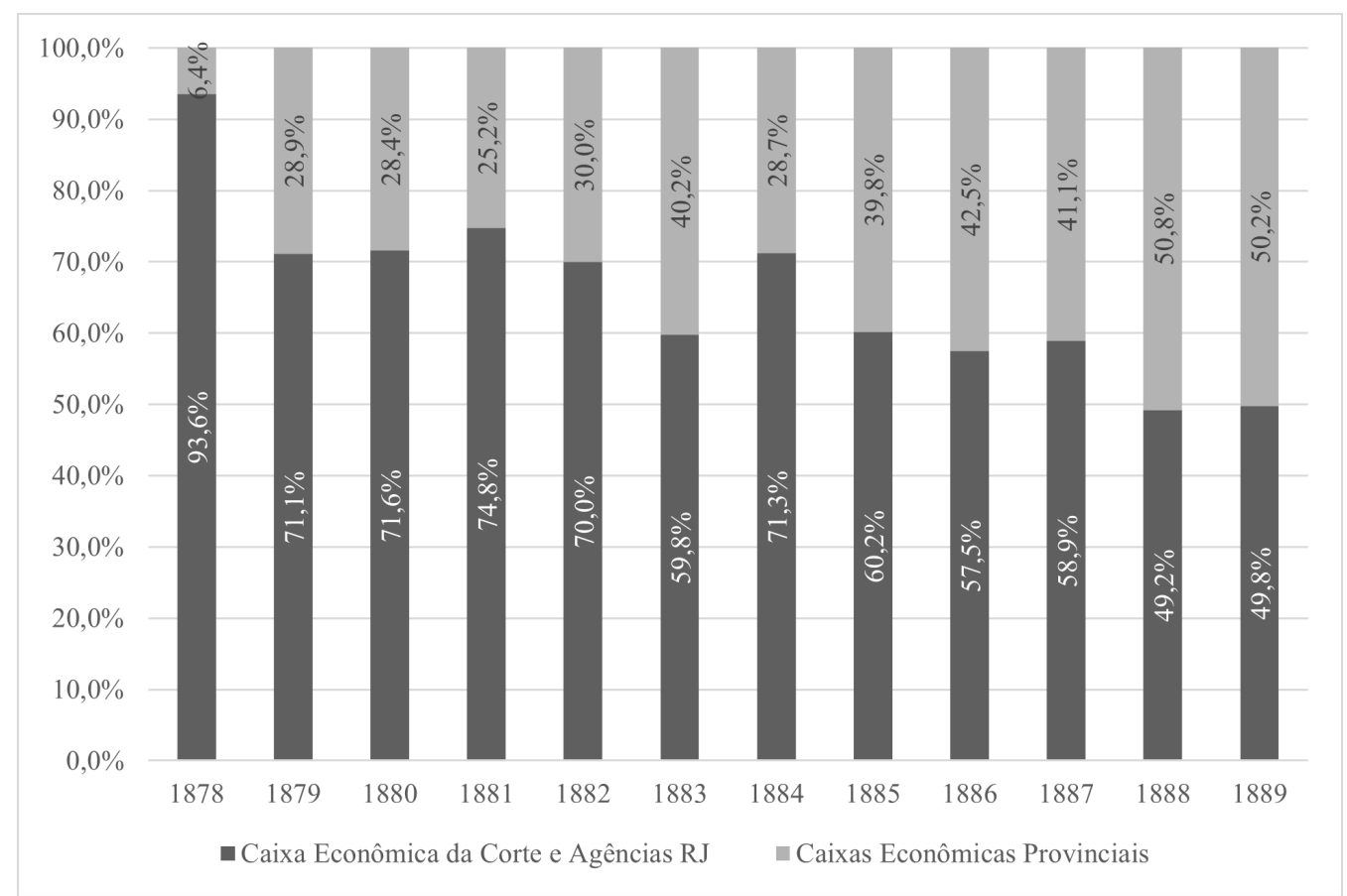

Fonte: Brasil, 1878-1889.

Gráfico 2. Proporção dos depósitos das Caixas Econômicas do Brasil em relação ao papelmoeda em circulação, 1861-1889 (em contos de réis)

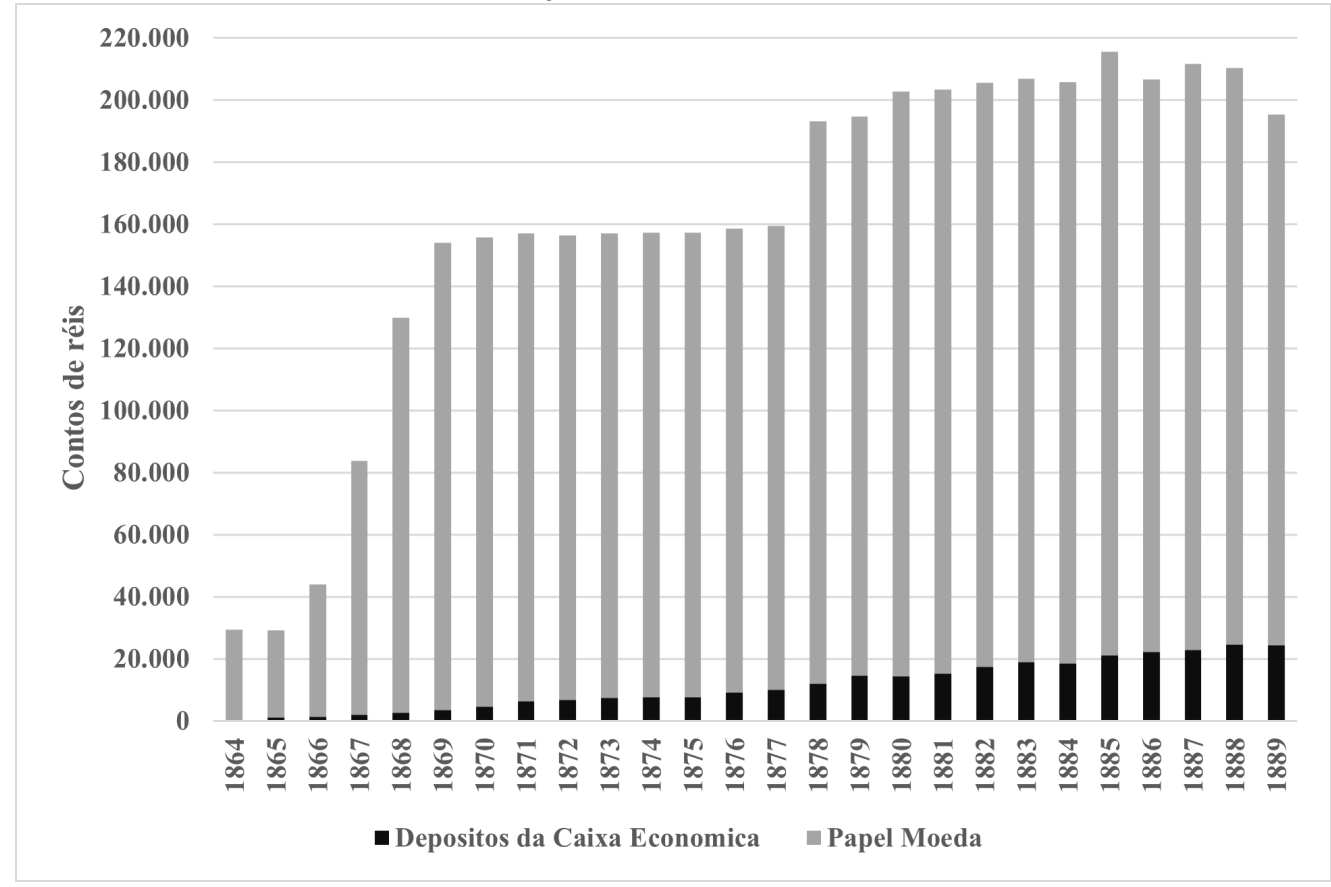

Fonte: Brasil, 1864-1889. 
Gráfico 3. Proporção dos depósitos das Caixas Econômicas do Brasil em relação ao papel-moeda em circulação, 1861-1889 (percentuais)

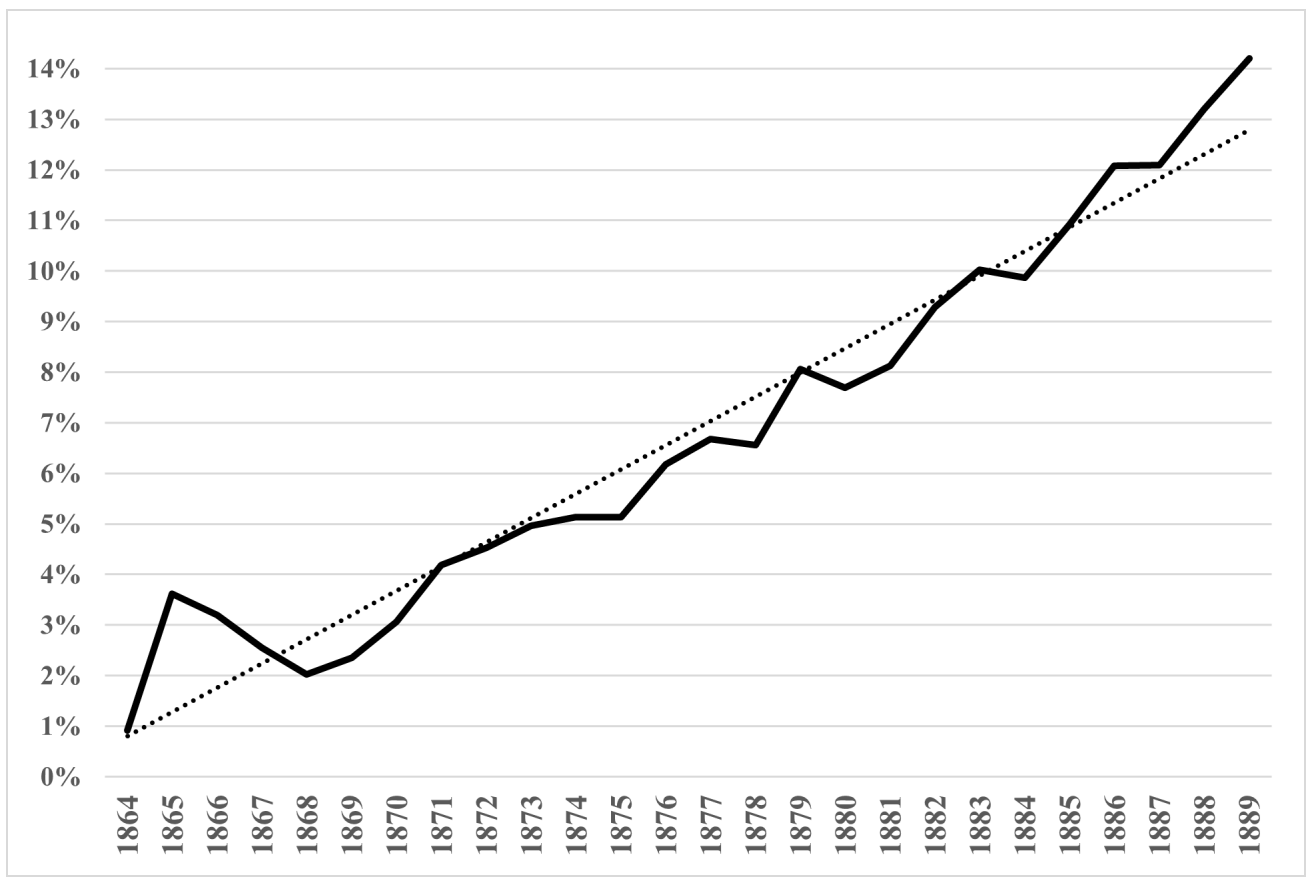

Fonte: Brasil, 1864-1889.

como demonstrado no Gráfico 3, mesmo havendo uma nova onda de emissão de moeda no ano de 1878, os depósitos coligidos nas caixas econômicas do Brasil correspondiam a sua função ao alcançarem a proporção de $7,69 \%$ do total de papelmoeda em circulação no ano de 1880.

A década de 1880 viu o papel-moeda em circulação alcançar o patamar máximo de cerca de 194 mil contos réis. Ainda assim, pelo desenvolvimento significativo das caixas econômicas, principalmente das caixas econômicas provinciais, a poupança brasileira alcançou a proporção de 14,21\% em relação ao total do papel-moeda em circulação.

É claro que a intenção não é considerar a poupança como o único mecanismo para diminuir a quantidade de papel-moeda em circulação. A própria política econômica apresentada nas décadas de 1870 e 1880 evitou a emissão de moeda a qualquer custo e demonstrou uma estagnação do papel-moeda em circulação. Essa política foi interrompida na década de 1890, a qual é marcada justamente pela crise conhecida como Encilhamento.

A seguir trataremos da analisar o desenvolvimento das caixas econômicas provinciais individualmente, utilizando-se de uma média geral dos depósitos como parâmetro para a comparação. Vale ressaltar que nosso intuito não é discorrer sobre cada uma das economias regionais. Temos como prioridade a comparação entre os desenvolvimentos das caixas econômicas provinciais e a abertura de discussões a respeito disso em outras oportunidades e com outros autores.
4. Análise da evolução das Caixas Econômicas Provinciais 1874-1889

Antes de iniciar a análise, é importante explicar como foi realizada a metodologia dessa análise. Os valores dos depósitos acumulados nas caixas econômicas provinciais foram retirados do balanço anual enviados por cada instituição ao Ministério da Fazenda. Esses balanços eram anuais e obrigatórios definidos pelo estatuto em 1874. No entanto, devido à dificuldade de algumas caixas econômicas provinciais se estabelecerem inicialmente, há ausência de dados para os primeiros anos.

Os valores totais e médias dos depósitos em cada capital estão dispostos cronologicamente e respeitando a ordem decrescente da população da cidade que sediava a caixa econômica. As estimativas populacionais foram calculadas a partir dos dados dos recenseamentos oficiais de 1872 e 1890. A partir de tais dados, foi inferido um índice de crescimento proporcional, o qual foi aplicado a cada ano. Apesar de não refletir as variações demográficas anuais, por falta de dados demográficos precisos, torna-se a única maneira de realizar uma análise serial das médias de poupanças levando em consideração o crescimento populacional. Deve-se considerar a falta de informação sobre o número de cadernetas coligidas em cada caixa econômica provincial. Infelizmente esses dados não foram fornecidos pelo balanço anual de cada caixa econômica 
Gráfico 4 - Depósitos acumulados nas caixas econômicas provinciais de Salvador, Recife, São Paulo e Ouro Preto, 1874-1889 (em contos de réis)

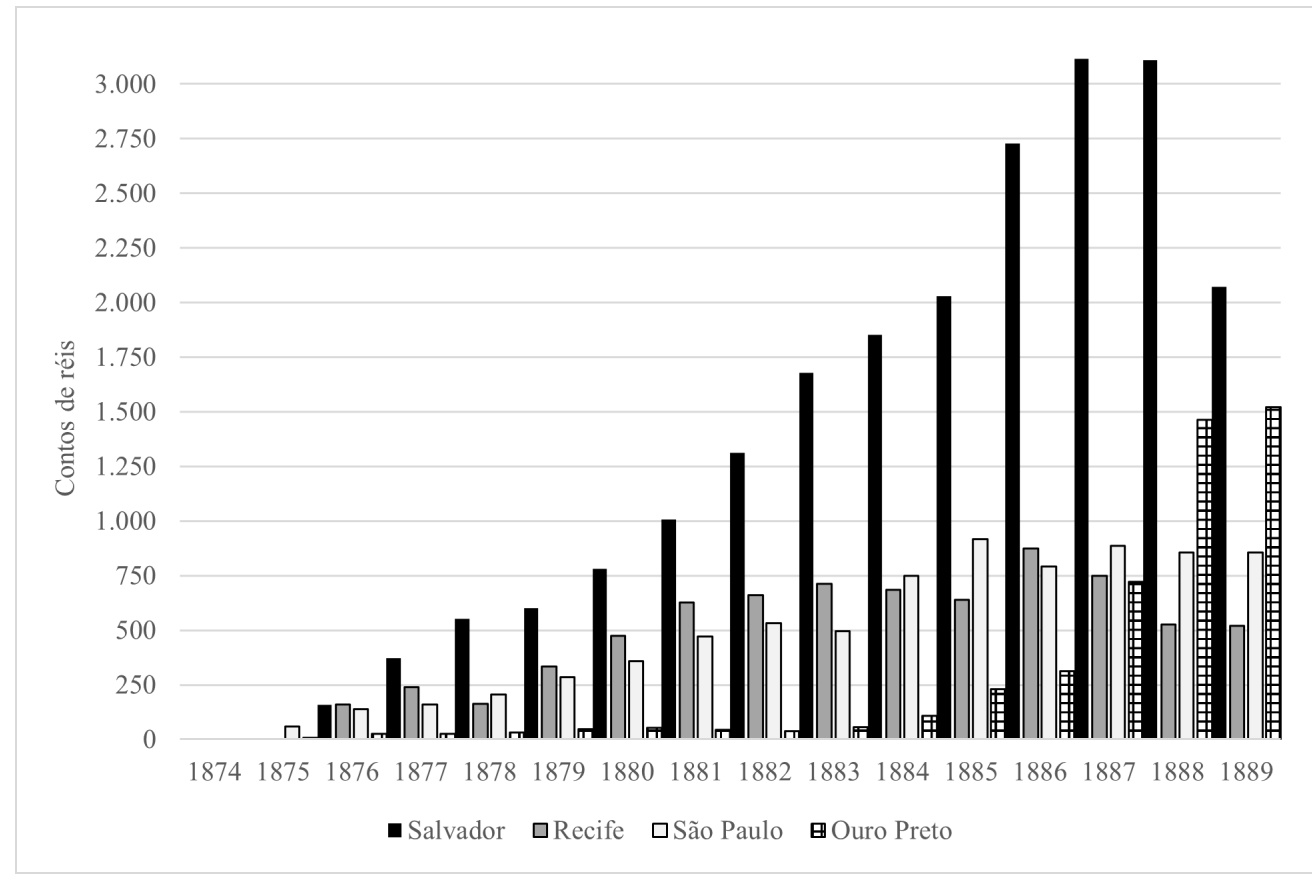

Fonte: Brasil, 1874-1889.

provincial e essa fonte não pode ser encontrada nos arquivos da Caixa Econômica Federal. Por fim, os valores apresentados para poupança e médias são nominais e a conversão para valores de dólar e libra pode ser feita por meio do Anexo A.

A cidade do Rio de Janeiro, também chamada de Corte ou Município Neutro, tinha cerca de 295 mil habitantes em 1872. Esse número aumentou para aproximadamente 522 mil habitantes no ano de 1890, em decorrência de uma série de reformas urbanas, bem como ondas imigratórias europeias, principalmente portuguesas. A Caixa Econômica da Corte, criada em 1861, teve uma taxa de crescimento de $31,4 \%$ anual. Seus valores saltaram de cerca de 48 contos de réis quando completara um ano de funcionamento em 1862 para aproximadamente de 11.400 contos de réis no ano de 1889 . O índice de crescimento populacional da cidade do Rio de Janeiro foi de $3,23 \%$ ao ano, enquanto o crescimento das cadernetas representou a média de $29 \%$ ao ano, isto é, quase dez vezes maior. Isso significava uma penetração do hábito de poupança maior que em qualquer outro lugar do império brasileiro. Era de se imaginar, as caixas econômicas já estavam em voga na sociedade carioca desde o início da década de 1830. Dessa forma, utilizaremos o desenvolvimento da Caixa Econômica da Corte como parâmetro para a comparação com todas as demais caixas econômicas provinciais.

No Gráfico 4 é demonstrado a evolução da captação de depósitos nas quatro capitais provinciais mais populosas do império brasileiro. A mais populosa capital de província era a cidade de Salvador na província da Bahia. Em 1872, segundo os dados do recenseamento oficial do império, a capital baia- na tinha 129.109 habitantes nas suas freguesias urbanas. Esse número se ascenderá a 174.412 no recenseamento de 1890 . O desenvolvimento da caixa econômica da Salvador foi lento ao levarmos em consideração o número de habitantes da cidade. Esse ritmo desacelerado de crescimento está relacionado à concorrência pela poupança soteropolitana. Na cidade de Salvador, havia ao menos uma caixa econômica particular - a Caixa Econômica da Bahia. Essa caixa privada acumulou grandes somas de capitais ao longo da década de 1870, tendo a publicado seu capital social de 2.074:388\$447 em 1880.

A evolução da quantidade de réis depositados na Caixa Econômica em Salvador manteve uma tendência de crescimento constante, interrompida apenas nos eventos que abalariam e colocariam fim à monarquia brasileira. Tais eventos nos últimos anos refletem em uma desconfiança, responsável por uma onda de saques da capital baiana. No Gráfico 5, observase que a média de poupança soteropolitana só ultrapassa a marca da média nacional no ano de 1886 e voltaria configurar abaixo no ano de 1889. O baixo valor de média de poupança em relação ao alto índice demográfico urbano nos leva a crê um maior número de caderneta. Ademais, considerando uma grande parcela de homens livres e pobres, ex-escravos na população urbana de Salvador, é razoável supor em uma popularização em do hábito de poupar.

Recife era o terceiro município mais populoso do Brasil em 1872 e continuou sendo até o final do período de nossa análise. Em termos demográficos, a capital de Pernambuco praticamente estagnou segundo os censos de 1872 e 1890. A Caixa Econômica do Recife teve um crescimento acentua- 
Gráfico 5. Médias dos depósitos acumulados nas caixas econômicas por habitante das capitais provinciais de Salvador, Recife, São Paulo e Ouro Preto. 1874-1889 (réis)

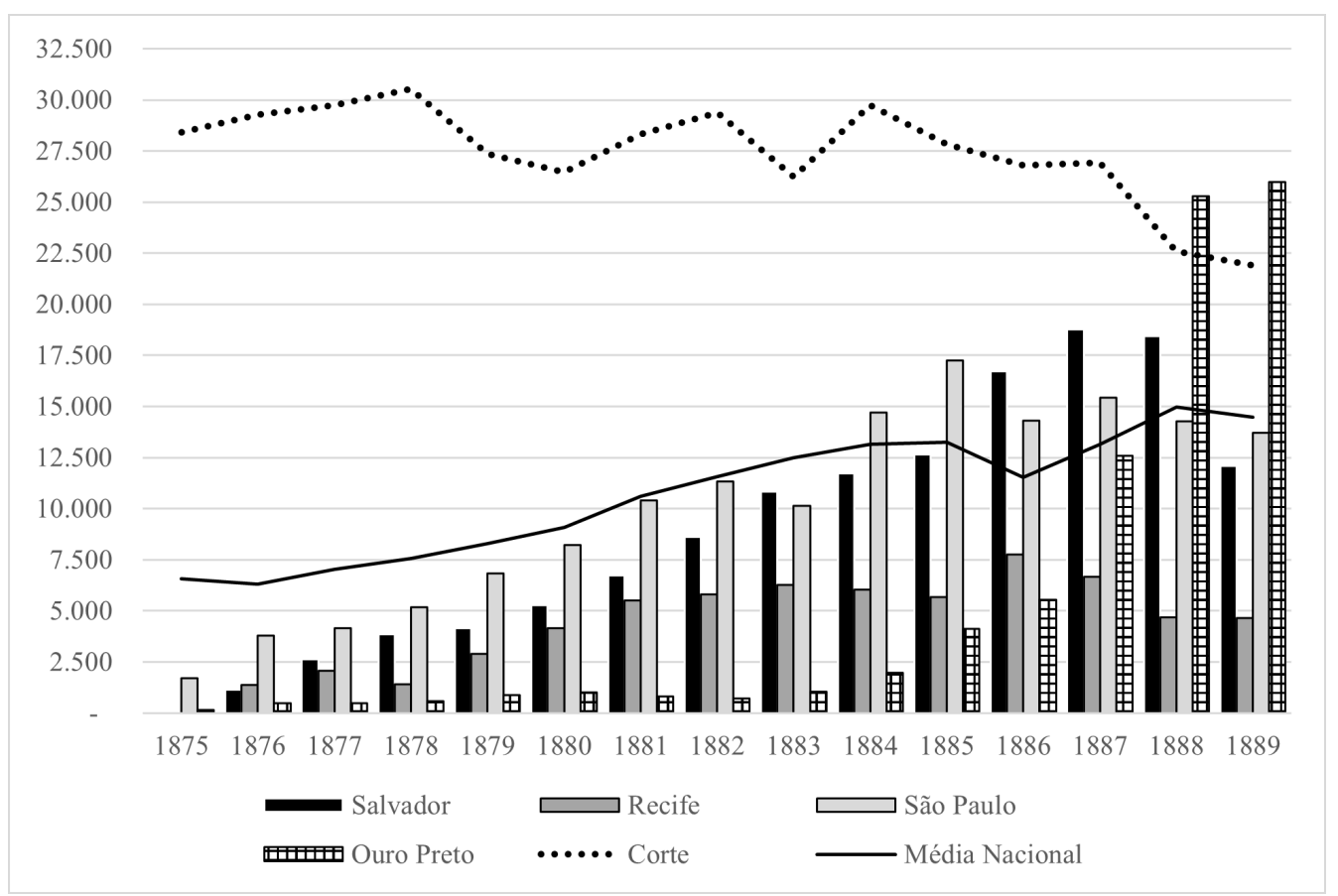

Fonte: Brasil, 1875-1889.

Gráfico 6. Depósitos acumulados nas caixas econômicas provinciais de Porto Alegre, Belém, Fortaleza e Manaus, 1874-1889 (em contos de réis)

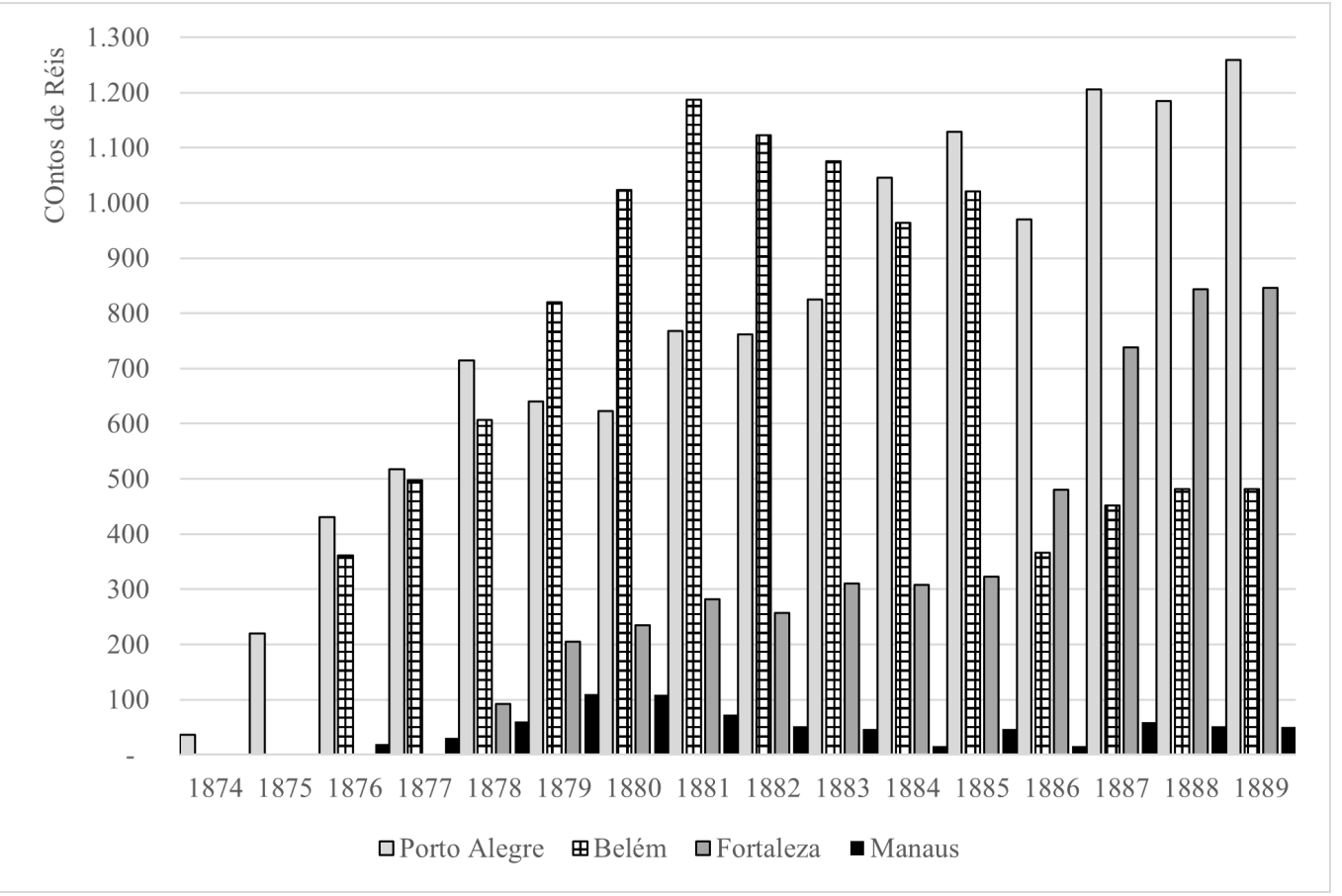

Fonte: Brasil, 1874-1889. 
do entre 1879 e 1881, com uma média de aproximadamente $60 \%$ no crescimento dos valores capitalizados nas cadernetas de poupança. Em termos da economia nacional, esse período antedeu um aumento dos meios de pagamento e, é claro, a quantidade de papel-moeda em circulação e coincidiu com uma estagnação econômica. O período seguinte, de 18811889 , representou uma verdadeira crise na poupança recifense. A média de crescimento foi negativa, representando cerca de $-1 \%$ de redução anual nos valores coligidos. Vale ressaltar que essa crise dos principais produtos pernambucanos já era percebida desde o começo da década de 1870. Tanto o açúcar quanto o algodão, principais produtos regionais, diminuíram drasticamente sua participação na pauta de exportações, principalmente devido a concorrência internacional e ao aumento do café do café produzido no Rio de Janeiro, São Paulo e Minas Gerais (Marcondes, 2005: 108).

São Paulo, por sua vez, não era uma capital provincial tão populosa quanto as demais do Gráfico 4, no entanto apresentou o índice de crescimento mais elevado entre as quatro citadas no gráfico e o quinto mais elevado índice de crescimento habitacional entre todas as províncias. A Caixa Econômica de São Paulo demonstrou um crescimento no valor total de depósitos de cerca de $13 \%$ ao ano, tendo o crescimento com maior destaque no ano de 1884 , com cerca de $51 \%$ no aumento da poupança acumulada. Esse aumento pode estar relacionado a alguns fatores: 1) o aumento das exportações brasileiras e o preço da saca de café no mercado mundial, as quais São Paulo se destacava pela produção do café no Oeste Paulista (Marquese, 2013: 2) aumento do meio-circulante nacional depois de uma série de quatro anos com redução; 3) efeito positivo das discussões e propostas de reforma no estatuto das caixas econômicas brasileiras, a qual foi seguida para o ano de 1885 e, sendo realizada uma proposta bem diferente da inicialmente indicada, infere o aumento das retiradas em 1887.

Ouro Preto era uma capital populosa, mas bem inferior às demais da comparação, com exceção de São Paulo. No entanto, a capital representava a província com o maior número de municípios brasileiros e, de longe, a maior população provincial. Mesmo com esse potencial demográfico, a Caixa Econômica de Ouro Preto do governo imperial teve dificuldade para instalar e se desenvolver. Sua dificuldade era muito clara e específica - a concorrência com a Caixa Econômica Particular de Ouro Preto, de capitais privados e que já era consolidada há anos na cidade (1838). Essa Caixa Econômica particular detinha, em 1889, cerca de 3500 a 3700 contos de réis em cofre e mais de 50 contos em ações (Gambi et al 2019, 22). Esse alto valor coligido nos demonstra claramente a dificuldade da Caixa Econômica de Ouro Preto provincial de se estabelecer.

A Caixa Econômica de Ouro Preto teve um crescimento considerado tímido entre 1877 e 1882, com cerca de 10\% ao ano. No entanto, os valores de poupança coligidos eram baixos. Nesse período citado anteriormente, a instituição de poupança provincial de Minas Gerais aumentou de cerca 25 contos em 1877 para cerca 38 contos de réis. Um valor irrisório se comparado com os capitais poupados na concorrente privada, a qual detinha em 1882 mais de 3.000 contos de réis somente em aplicações de Dívida Pública. A situação se inverte no final do período analisado. A Caixa Econômica de Ouro Pre- to demonstra uma taxa de crescimento de $233 \%$ nesses anos, enquanto a sua concorrente demonstrava redução no seu saldo, provavelmente em decorrência das incertezas da abolição da escravidão e do novo regime político.

O Gráfico 5 demonstra o desenvolvimento das médias nacionais. Essas médias foram calculadas a partir dos dados gerais da população em cada capital de província, uma vez que não há dados concretos e serializados para o número de cadernetas em cada caixa econômica provincial no período analisado. No Gráfico 5 podemos perceber que todas as caixas econômicas provinciais expostas no gráfico ultrapassam a Média Nacional, a qual demonstra tendência de crescimento nos anos finais. Não obstante, ainda que a média da Corte estivesse em declínio desde 1884, apenas a Caixa Econômica de Ouro Preto a ultrapassou. Uma média alta indica uma maior capacidade de poupança, mas não necessariamente indica uma igualdade econômica maior. Pelo contrário, no caso das caixas econômicas, é notório uma forte participação popular, porém responsável por apenas uma minúscula parte dos valores capitalizados. Então, é razoável supor que a média alta de Ouro Preto, ultrapassando a da Corte, significa uma transferência de capitais em poucas cadernetas, principalmente devido à mudança de estatuto que permitia entradas de qualquer valor.

O Gráfico 6 segue a análise com um novo bloco de caixas econômicas provinciais de Porto Alegre, Belém, Fortaleza e Manaus. A Caixa Econômica de Porto Alegre foi a primeira a ser estabelecida a nível provincial e demonstrou um desenvolvimento rápido nos seus primeiros anos. A cidade de Porto Alegre, em 1872, era a $6^{a}$ menor capital provincial em termos populacionais. O crescimento habitacional da capital gaúcha foi significativo, alcançando o patamar de $6^{a}$ maior em termos populacionais em 1890 (Gritti, 2001). Em menos de um ano de atividades, a Caixa Econômica gaúcha acumulava cerca de 219 contos de réis, um valor bem superior às demais caixas econômicas provinciais com um ano de criação. Entre 1876 e 1889, o crescimento dos valores de depósitos foi na média de $16 \%$ ao ano, subindo de cerca 430 contos de réis em 1876 para aproximadamente 1.258 contos de réis em 1889 .

Os depósitos gaúchos ensaiaram uma queda nos seus valores no ano de 1886, provavelmente mediado pela queda nas exportações do charque gaúcho e aumento de seus concorrentes uruguaios e portenhos (Vargas, 2015: 557). No entanto, terminaram o período analisado com tendência de crescimento.

A capital paraense era uma das mais populosas do império tanto em 1872 quanto em 1890. A província paraense teve uma tradição produtiva na cultura do arroz e cacau, mas, ao longo do século XIX, se destacou pela expansão da extração borracha. Na primeira metade da década de 1870, a goma elástica representou cerca de $82 \%$ de toda a exportação paraense, seguida por $9 \%$ do cacau (Marcondes, 2005: 124).

A Caixa Econômica de Belém, ao contrário da gaúcha, teve um período crítico em seu desenvolvimento. Essa caixa econômica paraense teve um vertiginoso crescimento inicial com a média de $27 \%$ ao ano entre 1877 e 1881, seguida por uma queda drástica de $16 \%$ ao ano entre 1882 e 1886 . Em meio ao ciclo da extração da borracha, a poupança paraense não acompanhava o ritmo das exportações da província. Os últi- 
Gráfico 7. Médias dos depósitos acumulados nas caixas econômicas por habitante das capitais provinciais de Porto Alegre, Belém, Fortaleza, Manaus e Província do Rio de Janeiro, 1874-1889 (réis)

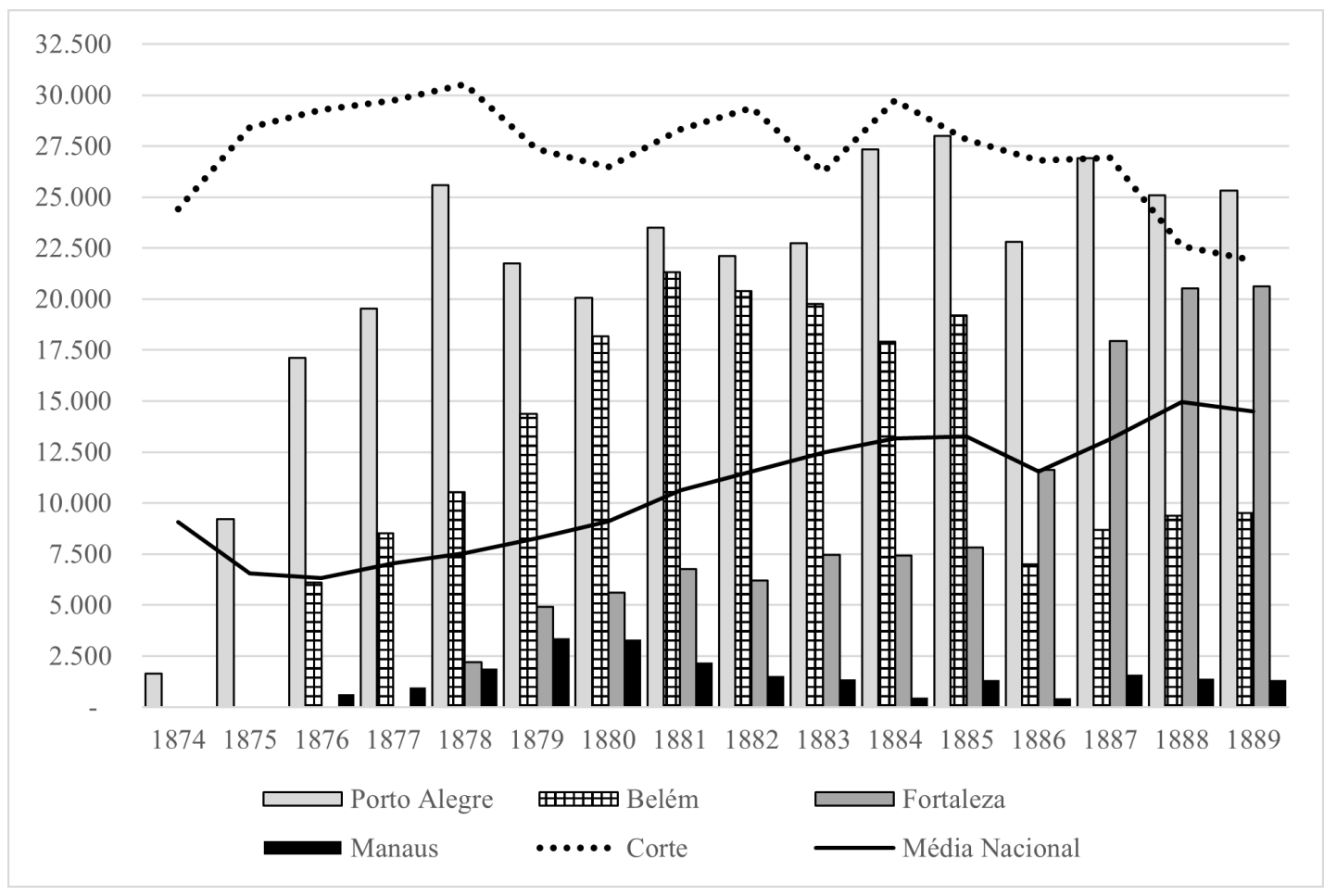

Fonte: Brasil, 1874-1889.

mos anos do período analisado demonstraram uma retomada da poupança. A Caixa Econômica de Belém detinha em 1877 cerca de 497 contos de réis e encerrara o período monárquico brasileiro com aproximadamente 481 contos de réis, sendo que alcançou a soma máxima de 1.020 contos de réis no ano de 1885. É preciso maiores investigações sobre a economia provincial para compreender a corrida de saques ocorrida na capital paraense.

A capital cearense, Fortaleza, demonstrou um comportamento de estagnação com uma pequena diminuição populacional de cerca de 42 mil habitantes para aproximadamente 41 mil habitantes entre os recenseamentos de 1872 e 1890. Ainda assim, a cidade de Fortaleza se configurava como a $8^{a}$ capital de província mais populosa no país em 1890. A Caixa Econômica de Fortaleza foi planejada para começar suas atividades em 1878, mas, de fato, iniciou apenas no início de 1879, provavelmente em decorrência da grande seca (1877-1879). A instituição teve um desenvolvimento de cerca de $17 \%$ ao ano, desconsiderando o primeiro ano. O período de maior desenvolvimento dos depósitos da caixa econômica cearense foi entre os anos de 1886-1887, no qual a média de crescimento representou 51\%. Mesmo após o enfrentamento de uma longa seca e com ondas emigratórias (Lima, 2010), a Caixa Econômica de Fortaleza tinha acumulado cerca de 845 contos de réis no ano de 1889.

Por fim, Manaus foi a capital, entre as demais capitais provinciais, que demonstrou o maior índice crescimento popula- cional. A cidade tinha cerca de 29 mil moradores segundo o recenseamento de 1872 e saltou para aproximadamente 39 mil no censo de 1890. Esse aumento populacional está ligado às secas do nordeste brasileiro, bem como o boom da extração da borracha, a qual foi atraiu muitos migrantes para o território amazonense. Não obstante, a Caixa Econômica de Manaus teve grandes dificuldade de se desenvolver, apesar de seu início ainda no ano de 1877. A média do crescimento revela um valor discrepante de $37 \%$ ao ano, no entanto, os valores acumulados pelos depósitos foram baixos. A Caixa Econômica amazonense possuía em cofre cerca de 30 contos de réis em 1877 e terminou o período da análise com aproximadamente 50 contos de réis em 1889. O ápice da instituição foi no ano de 1879 com o total de 110 contos de réis, a partir de então um número cada vez maior de saques ocorreu. É preciso uma investigação específica para compreender esse aumento drástico nos saques.

O Gráfico 7 apresenta as médias das caixas econômicas provinciais citadas anteriormente e as compara com as médias da Corte e a média nacional. Analisando a comparação das médias, é possível verificar que a média dos depósitos por habitante da Caixa Econômica da Porto Alegre foi a única no gráfico a ultrapassar a média da Corte. Isso acontece no ano de 1888 para 1889, quando houve um pânico de desconfiança na instituição de depósitos da Corte. Esse pânico foi localizado e não pôde ser observado nas demais caixas econômicas provinciais expostas no Gráfico 7. Todas as caixas econômicas 
Gráfico 8. Depósitos acumulados nas caixas econômicas provinciais de Teresina, Maceió, N.S. do Desterro, São Luís e Curitiba, 1874-1889 (em contos de réis)

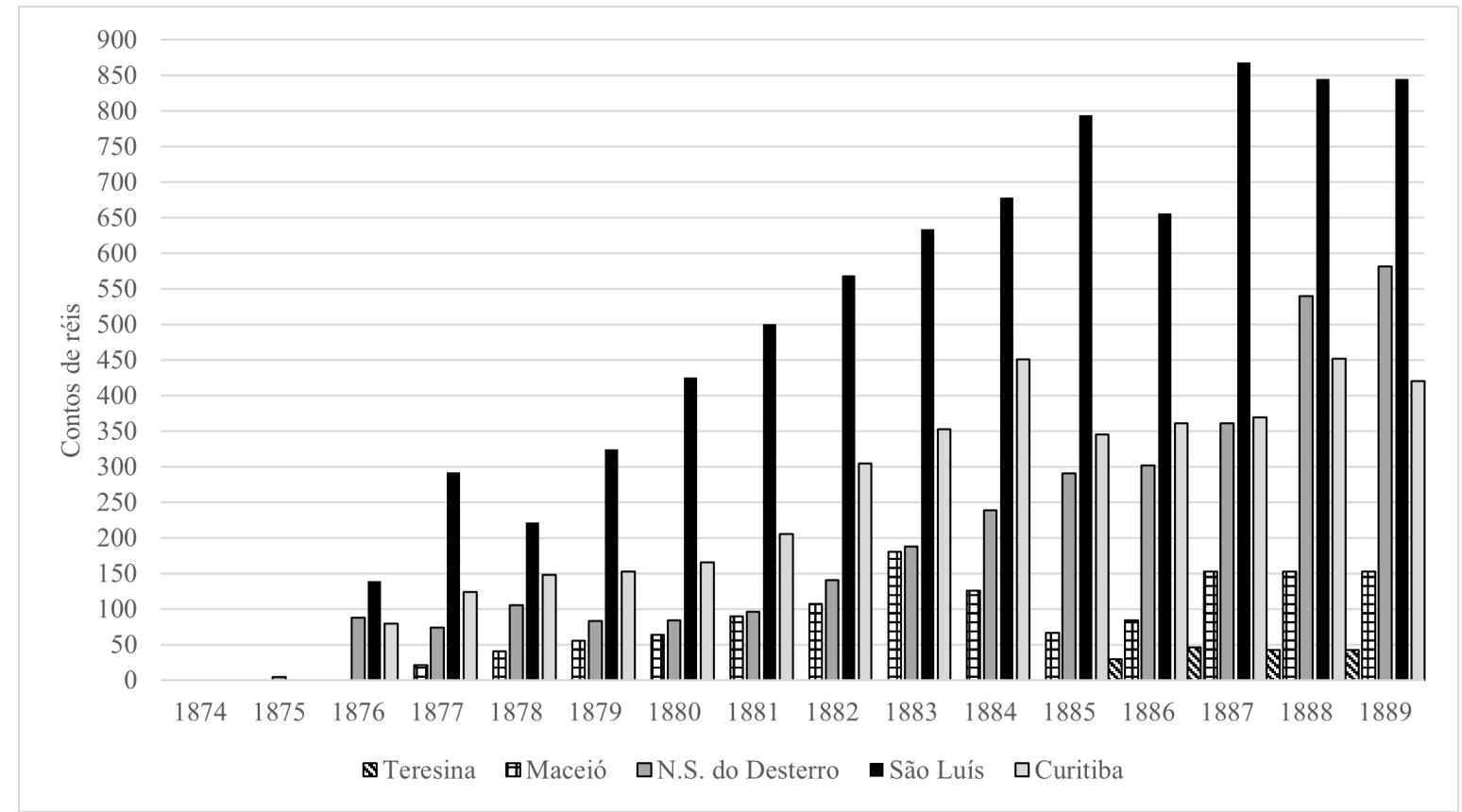

Fonte: Brasil, 1874-1889.

provinciais do gráfico superaram a média nacional em algum momento do período, no entanto, a de Belém reduziu drasticamente a média após o ano de 1885, ao mesmo tempo que a de Fortaleza ultrapassara a média nacional em 1886.

O Gráfico 8 representa os valores de depósitos acumulados nas caixas econômicas províncias de Teresina, Maceió, N. S. de Desterro (atual Florianópolis), São Luís do Maranhão e Curitiba. Apesar de ter iniciado suas atividades em 1875, a Caixa Econômica de Teresina, no Piauí, somente teve seus balanços expostos nos relatórios do Ministério da Fazenda a partir de 1886. O primeiro registro do total depositado nessa caixa econômica piauiense registrou o total de cerca de 29 contos de réis, o qual cresceu para aproximadamente 42 contos de réis em 1889. É preciso recuperar as lacunas para fazer qualquer análise sobre o desenvolvimento dessa caixa econômica provincial.

Maceió, por sua vez, teve uma caixa econômica provincial ativa desde 1878. A capital da província de Alagoas tinha uma população de 31.498 habitantes segundo o censo de 1890, o que a fazia a $12^{\text {a }}$ capital provincial mais populosa. A Caixa Econômica de Maceió apresentou uma taxa de crescimento de aproximadamente $19 \%$ ao ano (excetuando o primeiro), no entanto, o volume de depósitos não fora muito significativo. Em 1889 havia apenas cerca 152 contos de réis nos cofres dessa caixa econômica, tendo o seu valor máximo de 180 contos de réis alcançado no ano de 1883.

A capital da província de Santa Catarina, Nossa Senhora do Desterro (atual Florianópolis), teve um baixo crescimento populacional no período analisado. Entre 1872 e 1890 a capital dessa província cresceu de 25.709 para 30.687 moradores, fazendo a $9^{a}$ capital menos populosa do império brasileiro.
Sua caixa econômica demonstrou uma taxa de crescimento dos valores dos depósitos de cerca de 18\% ao ano. Em 1877, a Caixa Econômica de N. S. do Desterro possuía cerca de 73 contos de réis e no ano de 1889, o valor havia subido para cerca de 580 contos de réis. $O$ maior período de crescimento fora entre os anos de 1881 e 1885, quando crescera na taxa de $29 \%$ ao ano. Essa caixa econômica só apresentou déficit nos valores de depósitos nos anos iniciais de 1877 e1879, quando ainda estava se estabelecendo.

A capital maranhense não era tão populosa quanto as demais capitais provinciais, tendo cerca de 31.604 moradores em 1872 e diminuído para 29.308 em 1890. A Caixa Econômica de São Luís do Maranhão apresentou um volume significativo de depósitos. A caixa econômica maranhense já em 1877 apresentava cerca de 291 contos de réis acumulados. No último ano da análise, 1889, o volume de depósitos totalizou cerca de 844 contos de réis, demonstrando uma taxa de crescimento de aproximadamente $19 \%$ ao ano. O fim da guerra civil norte-americana fez-se a economia maranhense sentir devido ao retorno à concorrência de sua cotonicultura, mas também na concorrência da questão servil escrava com a cafeicultura brasileira. Nessas duas pontas, a economia maranhense saiu prejudicada pelo aumento do custo de produção, bem como a diminuição do preço da mercadoria principal (Rolim Filho, 2016: 34).

Por fim, na cidade de Curitiba moravam 12.651 pessoas em 1872. Esse número aumentou para 24.553 no recenseamento de 1890. Esse aumento populacional está ligado diretamente ao fluxo de imigrantes europeus (alemães, poloneses e italianos) a partir da emancipação da província em 1854, mas prin- 
Gráfico 9. Médias dos depósitos acumulados nas caixas econômicas por habitante das capitais provinciais de Porto Alegre, Belém, Fortaleza, Manaus e Província do Rio de Janeiro, 1877-1889 (réis)

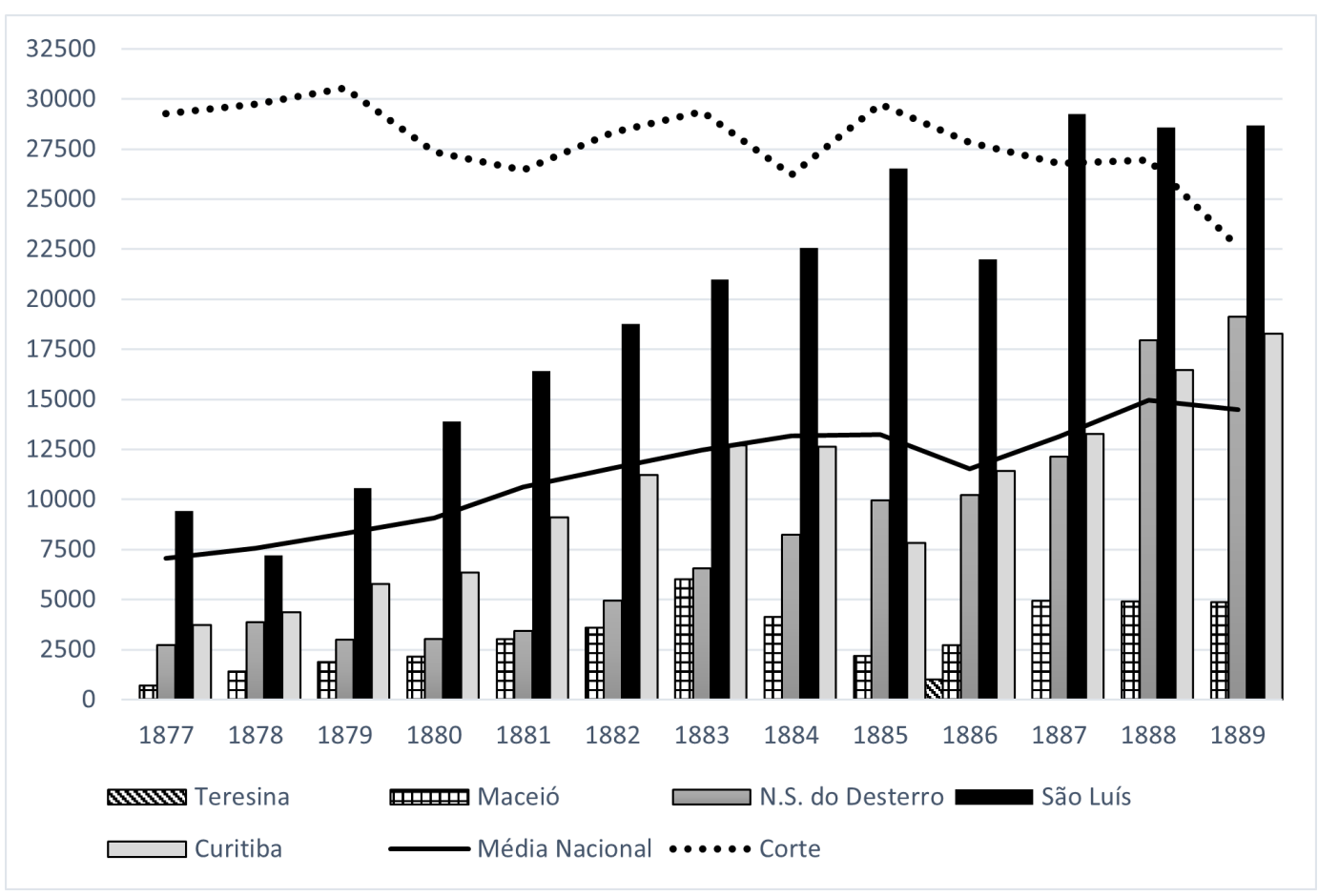

Fonte: Brasil, 1877-1889.

cipalmente na década de 1870 (Oliveira 1986). Mesmo com uma população considerada baixa em comparação com as demais capitais provinciais, a Caixa Econômica da Curitiba conseguiu se estabelecer ainda no começo da segunda metade do século XIX. Em 1877, a instituição de depósitos curitibana apresentava um volume de poupança acumulada de cerca de 123 contos de réis, enquanto no ano de 1889, esse volume havia crescido para próximo de 420 contos de réis. Isso representou um crescimento médio de $16 \%$ ao ano, com apenas dois anos deficitários - 1885 e 1889.

No Gráfico 9 estão expostas as médias de depósitos por habitante nas capitais provinciais. As médias de depósito de Teresina são bem irrisórias devido ao fraco desenvolvimento da instituição de depósitos do governo nesse município. A Caixa Econômica de Maceió apresenta médias baixas, pois seu volume captado em depósitos não ultrapassou a marca de 152 contos de réis e a população do município estava acima de 31.000 habitantes, ou seja, havia um potencial de poupança ainda não explorado devido a quantidade de habitantes da cidade. A Caixa Econômica de Nossa Senhora do Desterro e de Curitiba ultrapassam a média nacional no ano de 1888 (em torno de $15 \$ 000$ réis). Esse comportamento denotava uma maior participação dos moradores dessas cidades nos investimentos da poupança em um cenário que a média de depósitos da Caixa Econômica da Corte diminuía, principalmente devido a abolição da escravidão e as críticas políticas ao regime monárquico. Por fim, a Caixa Econômica de São Luís do Maranhão demonstrou um comportamento crescente ao longo dos anos e superior à média nacional em todos os anos, com exceção no de 1878. A média dos depósitos por habitantes da caixa econômica maranhense ultrapassa a média da Caixa Econômica da Corte a partir do ano de 1887. Esses valores das médias dos depósitos por habitantes da caixa econômica maranhense reafirma o desenvolvimento da instituição, do modelo de investimento naquela capital, bem como o aproveitamento do potencial de investimentos naquela população. Infelizmente não é possível inferir o perfil dos poupadores, uma vez que não há número de cadernetas divulgadas.

O Gráfico 10 apresenta os volumes de depósitos das econômicas provinciais de Cuiabá, Goiânia, Vitória, Aracajú e Natal. As caixas econômicas de Aracajú (Sergipe) e Natal (Rio Grande do Norte) foram criadas depois de 1885. Portanto, apresentam desenvolvimento inicial, com lacunas nos dados: a caixa econômica de Sergipe apresentou em 1889 o valor acumulado de 212 contos de réis, enquanto a caixa econômica de Natal possuí em valores totais de depósitos apenas 15 contos de réis. Bem como o caso da Caixa Econômica da Cidade da Paraíba (atual João Pessoa na Paraíba), criada apenas em 1886, detinha cerca de 26 contos em 1887 e um salto para 62 contos em 1888. Assim, devido à ausência de dados mais confiáveis, essa caixa econômica foi excluída dos gráficos.

A Caixa Econômica de Cuiabá (Mato Grosso) apresentou um desenvolvimento significativo com uma taxa de crescimento de cerca de 15\% ao ano. Em 1876, a instituição de de- 
Gráfico 10. Depósitos acumulados nas caixas econômicas provinciais de Cuiabá, Goiânia, Vitória, Aracajú e Natal, 1874-1889 (contos de réis)

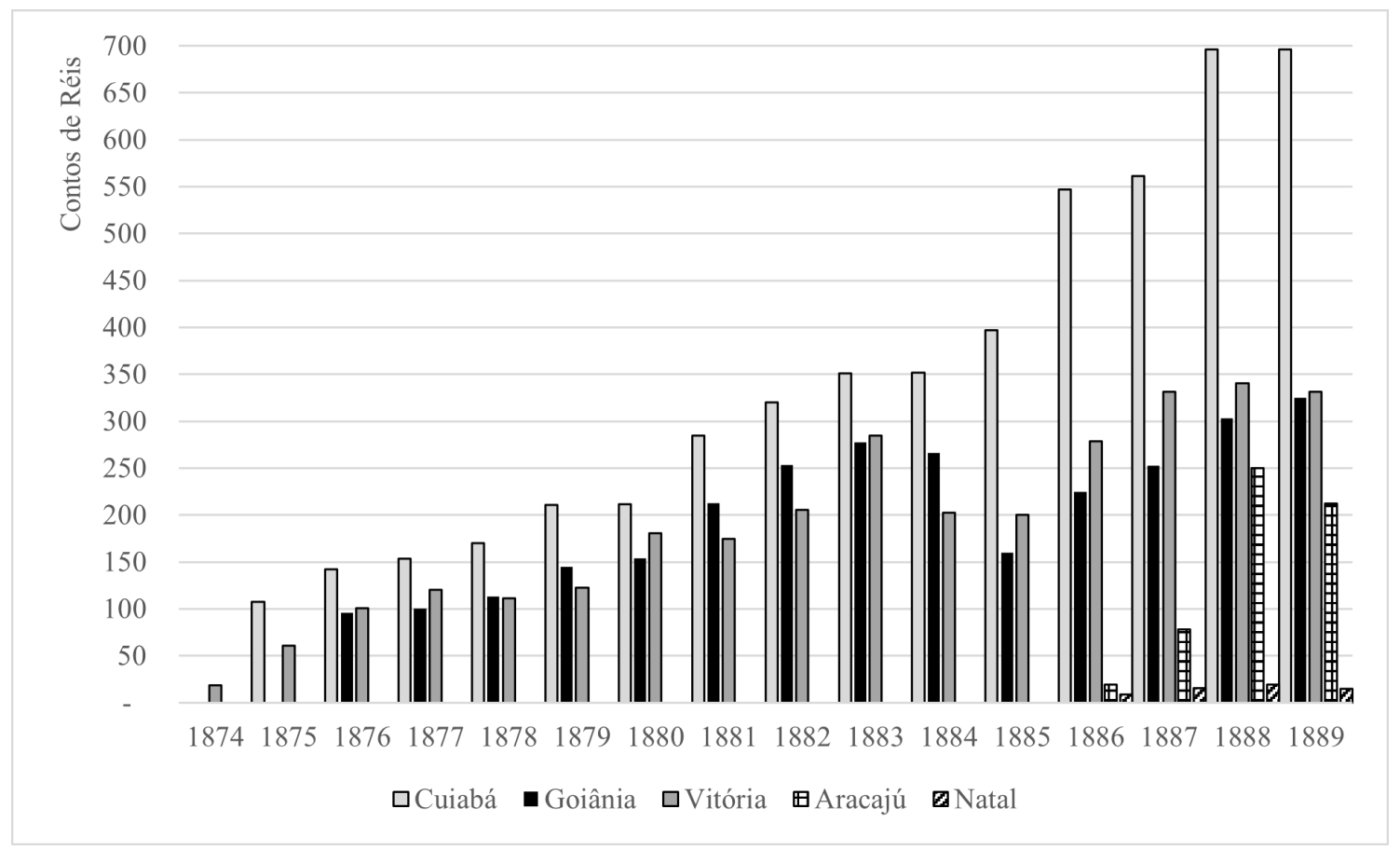

Fonte: Brasil, 1874-1889.

pósitos do governo em Cuiabá possuía cerca de 142 contos de réis acumulados e, no final do período analisado, alcançou a soma total de quase 696 contos de réis. O que chama bastante atenção é a proporção do volume dos depósitos com a população da capital mato-grossense. Em 1872, Cuiabá possuía cerca de 11 mil moradores. Esse número aumentou para cerca de 18 mil segundo o recenseamento de 1890. Quer dizer, uma cidade com apenas 18 mil habitantes - a quinta menor capital provincial - acumulou quase 700 contos de réis.

Por outro lado, Vitória era uma cidade com pouco menos de 17 mil habitantes em 1890, no entanto, bem próxima à Corte (levando em consideração malha ferroviária que já cobria o interior da província do Rio de Janeiro) e acumulou menos da metade do total de depósitos de Cuiabá. O desenvolvimento da poupança da caixa econômica do Espírito Santo foi maior que a de Cuiabá em termos proporcionais, o que significou uma taxa média de crescimento de 16\% ao ano. Contudo, em termos absolutos, a caixa econômica da capital do Espírito Santo possuía cerca de 332 contos de réis depositados em 1889.

Bem similar ao caso da Caixa Econômica do Espírito Santo foi a de Goiás. Goiânia também era uma das 5 capitais com menor índice populacional do império brasileiro, com cerca de 17 mil habitantes em 1890. Sua caixa econômica provincial alcançara a soma de cerca de 324 contos de réis em 1889, de- monstrando uma taxa de crescimento de cerca de $12 \%$ ao ano.

No que se refere às médias dos depósitos por habitantes, conforme exposto no Gráfico 11, o que nos chama bastante a atenção são as médias de Cuiabá. A alta média de depósitos por habitante de Cuiabá nos dá a impressão de uma disseminação dos depósitos entre os habitantes, mas é justamente o contrário. Como sabemos que o hábito de poupança tinha dificuldade de ser constituído nas províncias mais distantes ao centro econômico do império brasileiro, é razoável supor que essa alta média significa cadernetas com somas significativas poupadas, isto é, poucas pessoas poupando muito dinheiro. A comparação com a Caixa Econômica de Vitória fortalece esse argumento. São capitais com populações similares, no entanto, a caixa econômica do Espírito possuía metade dos depósitos da Caixa Econômica de Cuiabá. Dessa forma, a mesma proporção se reflete nas médias. Para além da subjetividade da análise do hábito de poupança, a capital do Espírito Santo era uma cidade mais monetizada que Cuiabá, principalmente devido ao porto de Vitória, um importante posto comercial e integração de trocas. 
Gráfico 11. Médias dos depósitos acumulados nas caixas econômicas por habitante das capitais provinciais Cuiabá, Goiânia, Vitória, Aracajú e Natal, 1876-1889 (réis)

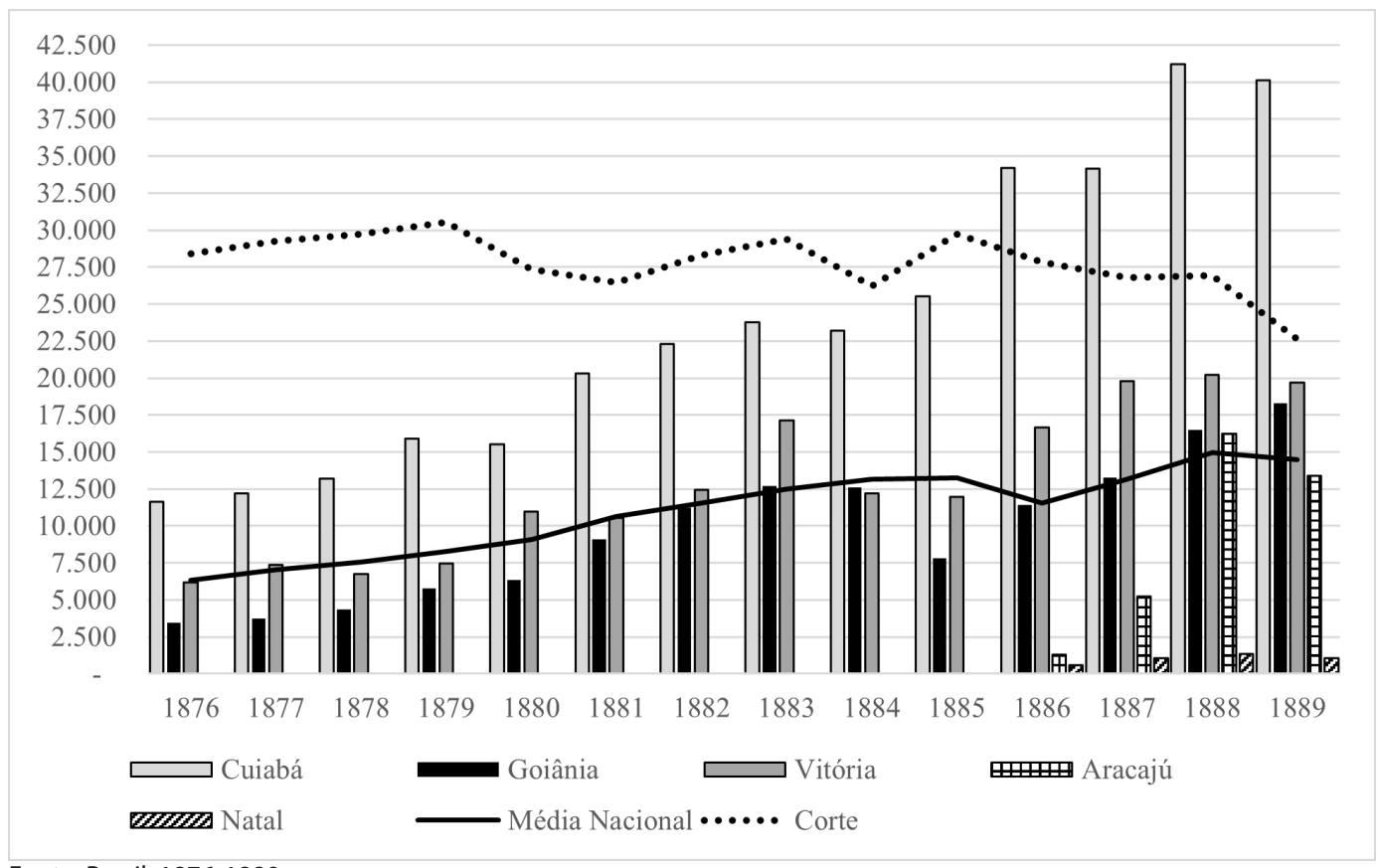

Fonte: Brasil, 1876-1889.

\section{Considerações Finais}

Como pode ser na Tabela 2, as taxas de crescimento agregado do total de depósitos das caixas econômicas provinciais ficam em torno de $16 \%$ ao ano, com algumas discrepâncias como a Caixa Econômica de Belém e de Ouro Preto, bem como a da Corte, uma vez que já estava em funcionamento desde 1861, assim o hábito de poupar na cidade do Rio de Janeiro estava bem mais difundido que nas demais cidades.

É razoável supor que, por meio das médias de valores de depósito por habitante, é possível perceber, nesses casos das caixas econômicas, uma maior concentração dos depósitos em poucas cadernetas de poupança. Vale ressaltar que, infelizmente, não possuímos a quantidade de depositantes nas caixas econômicas provinciais, mas na razão dos valores depositados e sua relação com a população estimada para cada capital de província, denotamos esse indício de uma menor penetração do hábito de poupar e da capacidade de poupança.

Por fim, o total de depósitos acumulados no último ano da análise, e último ano da monarquia brasileira, representou a soma de aproximadamente 22.300 contos de réis, o que representava, como dito anteriormente, cerca de $14 \%$ de todo o papel-moeda em circulação. As caixas econômicas brasileiras, administradas pelo governo imperial, tinham essa prerrogativa explícitas em seus objetivos fundacionais de ser um dos instrumentos de controle de papel-moeda em circulação. Não cabe nesse trabalho analisar o impacto dos depósitos públicos na circulação de papel-moeda no Brasil, mas, é possível dizer que essas instituições vinham contribuindo para esse objetivo. Ademais, apesar da larga diferença entre os valores acumulados na Corte e nas demais províncias, é importante ressaltar que algumas capitais provinciais já alcançavam depósitos acumulados próximos a 1.500 contos de réis, em situações com dificuldades originárias da má administração, da concorrência com caixas econômicas particulares e com proporções demográficas e, mesmo, níveis de renda bem inferiores à Corte.

A historiografia sobre caixas econômicas brasileiras é taxativa quanto ao lento desenvolvimento do hábito e valores da poupança brasileira no século XIX e início do XX. No entanto, essa letargia da poupança nas demais províncias devem ser relativizadas por meio da análise dos demais indicadores econômicos de cada região. Dessa forma, é importante que essa área de estudos continue a se desenvolver no Brasil e alcance pesquisadores regionais que se disponham a compreender esses índices de crescimento e relativizá-los regionalmente.

O objetivo dessa demonstração das poupanças das caixas econômicas províncias era demonstrar seus valores para uma comparação com a Caixa Econômica da Corte. Ao mesmo tempo, abrir oportunidades para novos trabalhos discutirem à fundo o desenvolvimento de cada caixa econômica provincial, relacionando-o com suas peculiaridade e características próprias da economia regional. 
Tabela 2. Taxa de Crescimento Agregada, Média de valores de depósito por habitante (réis) e Total de Depósitos acumulados em 1889 (réis) das Caixas Econômicas Provinciais

\begin{tabular}{|l|c|c|c|}
\hline $\begin{array}{c}\text { Caixa Econômica Pro- } \\
\text { vincial }\end{array}$ & $\begin{array}{c}\text { Taxa de Crescimento } \\
\text { Agregado (\%) }\end{array}$ & $\begin{array}{c}\text { Média de valores de depó- } \\
\text { sito por habitante (réis) }\end{array}$ & $\begin{array}{c}\text { Total de Depósitos } \\
\text { acumulados em 1889 } \\
\text { (em contos de réis) }\end{array}$ \\
\hline Aracajú & - & 9.042 & 212 \\
\hline Belém & 4,1 & 13.633 & 481 \\
\hline Cidade da Paraíba & 1,6 & 2.627 & 62 \\
\hline Corte (Rio de Janeiro) & 13,6 & 27.241 & 11.085 \\
\hline Cuiabá & 12,2 & 22.819 & 695 \\
\hline Curitiba & 16,7 & 14.287 & 420 \\
\hline Fortaleza & 11,9 & 9.928 & 845 \\
\hline Goiânia & 19,2 & 9.761 & 324 \\
\hline Maceió & 35,7 & 3.278 & 152 \\
\hline Manaus & 17,8 & 1.555 & 50 \\
\hline N. S. do Desterro & - & 7.240 & 580 \\
\hline Natal & 16,4 & 1.020 & 15 \\
\hline Ouro Preto & 11,5 & 5.444 & 1.522 \\
\hline Porto Alegre & 15,8 & 21.169 & 1.258 \\
\hline Recife & 11,8 & 4.642 & 520 \\
\hline Salvador & 9.545 & 2.072 \\
\hline São Luís & 18.528 & 844 \\
\hline São Paulo & 10.097 & 834 \\
\hline Teresina & 11.543 & \\
\hline Vitória & 15,5 & & \\
\hline
\end{tabular}

Fonte: Brasil, 1875-1889. Aracajú, Cidade da Paraíba, Teresina e Natal, por terem sido criadas já no final da década de 1880, apresentam taxas de crescimento extrapoladas por balanços anuais lançados de maneira acumulada.

Bibliografía

ALVARENGA, T. O. e SARAIVA, L. F. (2017): "A Caixa Econômica do Rio de JaneiFonte: Brasil, 1875-1889. Aracajú, Cidade da Paraíba, Teresina e Natal, por terem sido criadas já no final da década de 1880, apresentam taxas de crescimento extrapoladas por balanços anuais lançados de maneira acumulada.

ro, 1831-1859". In: Carlos Marichal; Tiago Gambi (org.), Historia bancária y monetária de América Latina (siglos XIX y XX). Nuevas perspectivas y agendas de investigación. Santander, Ediciones Universidad Cantabria, pp. 429-462.

ALVARENGA, T. O. (2018): "Os pequenos credores na bancarrota das casas bancárias cariocas em 1864". Revista do Arquivo Geral da Cidade do Rio de Janeiro, 15 , pp. 251-276.

ALVARENGA, T. O. e MANTUANO, T. (2020a): “As duas pontas da crise: as falências das casas bancárias em 1864 vistas de cima a baixo", América Latina en la Historia Económica, 27(3), e1043. DOI: 10.18232/alhe.1043. 2020.
ALVARENGA, T. O. (2020b): A Caixa Econômica da Corte: Desenvolvimento, Centralização e Expansão da poupança brasileira (1861-1889). Tese de doutorado do Programa de Pós-Graduação em História Social e da Escuela Internacional de Doctorado de la Universidad de Murcia. Universidade Federal Fluminense e Universidad de Murcia. Niteroi/Murcia.

ALVARENGA,T. O. (2021): "Depósitos e Depositantes das Caixas Econômicas Brasileiras 1861-1889", in Saraiva, L.F. Nabarro, W. E Castro, P.G. de. Atlas Histórico Econômico do Brasil no século XIX. Niteroi, Eduff. (no prelo).

BRASIL (1861-1889): Ministério da Fazenda. Proposta e Relatório. Rio de Janeiro Tipografia Nacional, nos anos de 1861 até 1889. Disponível em http://ddsnext.crl.edu/.

CHRISTEN-LECUYER, Carole (2005): "La mesure de l'efficacité sociale des Caisses d'épargne françaises au XIXe siècle", Histoire et Mesure, 3/4, pp. 139175.

GAMBI, Thiago F. R.; SILVA, Marcel P. da e VIEIRA, Eduardo J. (2019) "A Caixa Econômica Particular de Ouro Preto (1838-1901)", XIII Congresso Brasileiro de História Econômica e $14^{\circ}$ Conferência Internacional de História de Empresas. ABPHE. Criciúma.

GRITTI, Isabel Rosa (2001): Imigração e colonização polonesa no Rio Grande do Sul: a emergência do preconceito. Tese de Doutorado, Porto Alegre:,PUCRS. 
GUIMARÃES, Carlos Gabriel (2013): “O Banco Comercial e Agrícola no Império do Brasil: o estudo de caso de um banco comercial e emissor (18581862)". sÆEculum - Revista de História [29]; João Pessoa, jul./dez.

HORNE, Oliver H. (1947): A History of Savings Banks. Geoffrey Cumberlege. Oxford University Press. London.

LIMA, Viviane (2010): "Agenciamento e Agenciadores da emigração: a inserção dos trabalhadores cearenses na lavoura cafeeira (século XIX)". Histórica - Revista Eletrônica do Arquivo Público do Estado de São Paulo, 41, abr, São Paulo.

MARCONDES, Renato Leite (2005): Desigualdades regionais brasileiras: comércio marítimo e posse de cativos na década de 1870. Tese de Livre-Docência. Departamento de Economia da Faculdade de Economia, Administração e Contabilidade de Ribeirão Preto. Universidade de São Paulo.

MARQUESE, Rafael de B. (2013): "Capitalismo, escravidão e a economia cafeeira do brasil no longo século XIX." Sæculum - Revista de História, 29, 31 dez.

MATTOS, Ilmar Rohloff de (2004): O Tempo Saquarema. 5aedição, São Paulo: Editora Hucitec.

MOURA FILHO, Heitor P. de (2010): "Câmbio de longo prazo do mil-réis: uma abordagem empírica referente às taxas contra a libra esterlina e o dólar (1795-1913)", Cadernos de História, 11 (15), $2^{\circ}$ semestre. Belo Horizonte.

OLIVEIRA, Maria Cecília Marins de (1986): Os imigrantes e o ensino na província do Paraná. Educ. rev., Curitiba, 5, pp. 51-79.

ROLIM FILHO, Claudiomar M. (2016): Formação Econômica do Maranhão: de província próspera a estado mais pobre da federação. O que deu tão errado? Dissertação defendida no Programa de Pós-Graduação em Economia do Setor Público. Universidade de Brasília.

SHERMAN, F. J. (1934): Modern of Mutual Savings Banks: A narrative of their growth and development from the inception to the Present Day. New York, J. J. Little and Ives Company.

VARGAS, Jonas Moreira (2015): “Abastecendo plantations: A inserção do charque fabricado em Pelotas (RS) no comércio atlântico das carnes e a sua concorrência com os produtores platinos (século XIX)", História (são Paulo) 33 (2).
Anexo A. Séries Cambiais de Longo Prazo, em mil-réis por libra e por dólar (1861-1889)

\begin{tabular}{|c|c|c|}
\hline Ano & Mil-réis por Libra & Mil-réis por Dólar \\
\hline 1861 & 9,17 & 1,87 \\
\hline 1862 & 9,23 & 1,89 \\
\hline 1863 & 9,29 & 1,90 \\
\hline 1864 & 9,32 & 1,90 \\
\hline 1865 & 9,33 & 1,91 \\
\hline 1866 & 9,36 & 1,91 \\
\hline 1867 & 9,40 & 1,92 \\
\hline 1868 & 9,43 & 1,93 \\
\hline 1869 & 9,47 & 1,94 \\
\hline 1870 & 9,48 & 1,94 \\
\hline 1871 & 9,46 & 1,94 \\
\hline 1872 & 9,48 & 1,94 \\
\hline 1873 & 9,55 & 1,96 \\
\hline 1874 & 9,67 & 1,98 \\
\hline 1875 & 9,80 & 2,01 \\
\hline 1876 & 9,91 & 2,03 \\
\hline 1877 & 10,04 & 2,06 \\
\hline 1878 & 10,17 & 2,09 \\
\hline 1879 & 10,33 & 2,12 \\
\hline 1880 & 10,59 & 2,18 \\
\hline 1881 & 10,94 & 2,25 \\
\hline 1882 & 11,19 & 2,30 \\
\hline 1883 & 11,41 & 2,35 \\
\hline 1884 & 11,59 & 2,38 \\
\hline 1885 & 11,73 & 2,41 \\
\hline 1886 & 11,87 & 2,44 \\
\hline 1887 & 12,05 & 2,47 \\
\hline 1888 & 12,21 & 2,51 \\
\hline 1889 & 12,38 & 2,54 \\
\hline 1890 & 12,56 & 2,58 \\
\hline
\end{tabular}

Fonte: MOURA FILHO, 2010. Dados extraídos do Anexo - Séries Cambiais. 